\title{
Distribution and significance of rare earth elements in Cenomanian-Turonian phosphate components and mudstones from the Bohemian Cretaceous Basin, Czech Republic
}

\author{
Khaldoun Al-Bassam \& Tomáš Magna
}

\begin{abstract}
Samples from the upper part of Pecínov Member of the Peruc-Korycany Formation (upper Cenomanian), lower part of the Bílá Hora Formation (upper Cenomanian-lower Turonian) and lower part of the Teplice Formation (upper Turonian) were analyzed for contents of rare earth elements (REE), $\mathrm{P}_{2} \mathrm{O}_{5}, \mathrm{Y}$ and $\mathrm{U}$. The samples include glauconitic mudstones and sandstones, phosphate nodules, phosphate coprolites, sponges and tube-fills. The results indicate that carbonate-fluorapatite is the major host of REE in the Cenomanian-Turonian sequence, with REE most probably substituting for calcium in the apatite structure. The substantial proportion of REE was supplied from terrigenous material derived from highly weathered crystalline rocks of the Bohemian Massif and transported by rivers to the basin. The shale-normalized REE distribution shows a "bell-shaped" pattern, particularly developed in the phosphatebearing samples. Such a pattern could have been produced by local environmental redox conditions, preferential substitutions in the apatite phase, and/or later diagenetic processes, in addition to a possible signature of source rocks. The results suggest that all investigated units were deposited under various degrees of oxygen availability. Redox conditions indicators, such as Ce-anomaly and Ce/La ratio, suggest decreased oxygenation of the depositional environment from bottom to top in the upper parts of the Pecínov Member and in the phosphate nodules at the base of the Bílá Hora Formation at Pecínov quarry. The phosphate nodules and coprolites were in contact with seawater for an extended period of time to accommodate higher concentrations of REE, suggesting slow deposition. Further REE enrichment could have taken place later during reworking which allowed further mixing with seawater. The phosphate sponges with less REE were deposited in shallow marine environment and had less contact time with seawater prior to burial. The large REE enrichments, detected in the tubular phosphatic deposits, may be linked to a higher terrigenous input of REE-bearing minerals associated with the proximity to the continental source area during events of extreme sea level fall. $•$ Key words: rare earth elements, phosphate, mudstone, Cretaceous, Bohemian Cretaceous Basin.
\end{abstract}

Al-Bassam, K. \& Magna, T. 2018. Distribution and significance of rare earth elements in Cenomanian-Turonian phosphate components and mudstones from the Bohemian Cretaceous Basin, Czech Republic. Bulletin of Geosciences 93(3), 347-368 (8 figures, 6 tables). Czech Geological Survey, Prague. ISSN 1214-1119. Manuscript received July 18, 2017; accepted in revised form April 27, 2018; published online July 19, 2018; issued August 20, 2018.

Khaldoun Al-Bassam \& Tomáš Magna, Czech Geological Survey, Klárov 3, 11821 Praha 1, Czech Republic; albassam703@gmail.com

Rare earth elements (REE; La-Lu) are considered an important tool in studies of sedimentary rocks where they may indicate environmental conditions and track the ultimate source rocks. They have commonly been used to investigate redox conditions of the environment (Elderfield \& Pagett 1986, Wright et al. 1987, Shields \& Stille 2001), record sea-level fluctuations (Wilde et al. 1996), and track the sources of REE input into marine environment (Martin et al. 1976, Elderfield \& Greaves 1982, Hoyle et al. 1984, Goldstein \& Jacobsen 1988, Elderfield et al. 1990, Mitra et al. 1994). Rare earth elements are found in all types of sedimentary rocks, but they are in particular present in high concentrations in marine phosphorites which are considered by some as a potential alternative source for the conventional natural REE resources (Altschuler et al. 1967, British Geological Survey 2011, Emsbo et al. 2015). They are also concentrated in $\mathrm{Fe}-$ and Mn-oxyhydroxide precipitates, which are taken as an efficient trap for REE in fresh-water and marine environments (Fleet 1984, Ruhlin \& Owen 1986).

\section{REE in seawater}

There was a general agreement in the early studies that rivers are the dominant source of REE in seawater deriving 
their REE budget from weathering of continental rocks (Piper 1974), with additional input of REE by Aeolian transport, aluminosilicates and $\mathrm{Fe}-\mathrm{Mn}$ oxyhydroxides (Windom 1969), submarine volcanism (Piper et al. 1975), and by submarine hydrothermal systems (Fleet 1984, Goldstein \& Jacobsen 1988, Olivarez \& Owen 1991). However, subsequent investigations indicated that fluvial input is more complex; field and laboratory studies (Martin et al. 1976, Hoyle et al. 1984, Goldstein \& Jacobsen 1988) have shown that a significant portion of REE in river waters is removed in estuaries, probably through a combination of sorption and co-precipitation reactions (Fleet 1984). As a consequence, adsorptive scavenging by $\mathrm{Fe}-\mathrm{Mn}$ oxyhydroxides is thought to limit the REE budget in seawater and REE are supplied to the ocean mainly as particulate material of which very little is dissolved (Sholkovitz et al. 1994). It should be noted that the dissolution of $\mathrm{Fe}-\mathrm{Mn}$ oxyhydroxides in dysoxic and anoxic marine environments can locally increase REE concentrations in seawater by an order of magnitude (German et al. 1991) and REE concentrations more than two orders of magnitude higher than in seawater in shallow subsurface pore fluids were also reported (Abbott et al. 2015).

Seawater exhibits progressive enrichment of heavy rare earth elements (HREE) relative to light rare earth elements (LREE) paralleled by negative Ce-anomaly (Høgdahl et al. 1968). This depletion in Ce reflects its oxidation to the strongly insoluble $\mathrm{Ce}^{4+}$ under oxic to suboxic conditions in the modern open ocean (Piper \& Bau 2013), while preferential removal of Ce and LREE by $\mathrm{Fe}-\mathrm{Mn}$-oxyhydroxide particles appears to be responsible for the characteristic REE pattern of modern seawater (Sholkovitz 1994). Elderfield \& Pagett (1986) have set the Ce-anomaly (defined as $\log \left[3 \times \mathrm{Ce}_{\mathrm{N}} /\left(2 \times \mathrm{La}_{\mathrm{N}}+\mathrm{Nd}_{\mathrm{N}}\right]\right.$; normalized to North American Shale Composite (NASC) of Haskin \& Haskin 1966) divide between oxic and anoxic conditions at zero. Wright et al. (1987) applied the same definition of Ce-anomaly, but used the boundary value of -0.1 to define the oxic/anoxic boundary, which would account for the mixing effect resulting from vertical diffusion or horizontal transfer of anoxic signatures and the existence of a transition zone. The Ce-anomaly in the Atlantic seawater was found to range from -0.74 to -0.22 (Høgdahl et al. 1968, Elderfield \& Greaves 1982, De Baar et al. 1983) with more negative values found in deeper parts of the ocean.

\section{REE in marine sediments}

The REE patterns of open marine sediments are similar to that of seawater with negative Ce-anomaly and HREE enrichments but are markedly different from those of rivers, hydrothermal, Aeolian and diagenetically-modified patterns of marine sediments, which are characterized by LREE and middle rare earth elements (MREE) enrichment, and the absence of Ce-anomaly (Elderfield \& Greaves 1982, Elderfield et al. 1990, Mitra et al. 1994). The REE patterns of modern marine authigenic carbonates, barytes and phosphates show a close similarity to REE patterns of seawater (Shields \& Stille 1998), and all marine sedimentary phosphorites formed in marine upwelling systems mimic REE pattern of open seawater (Altschuler et al. 1967, McArthur \& Walsh 1984, Jarvis et al. 1994, Ilyin 1998, Shields \& Stille 2001, Shields \& Webb 2004, Aba-Hussain et al. 2010, Emsbo et al. 2015, Abed et al. 2016). Shale-normalized REE patterns in marine sediments that resemble modern seawater patterns are mostly interpreted as a primary signature and reflecting deep marine sources of REE (Elderfield \& Pagett 1986, Wright et al. 1987, Piper et al. 1988, Picard et al. 2002, Martin \& Scher 2004). Deviations from the seawater pattern are considered by some researchers to record post depositional alteration, where redistribution of REE among detrital and authigenic phases occurs during diagenetic equilibration of phosphate phases with pore water (McArthur \& Walsh 1984, Ilyin 1998, Shields \& Stille 2001, Shields \& Webb 2004, Bright et al. 2009). The anomalous departures of REE patterns in marine sediments from seawater pattern, mostly demonstrated by Ce-anomaly, are thought by many authors to reflect the paleoredox conditions of primary deposition of these sediments (Morad \& Felitsyn 2001). However, the Ceanomaly appears to be more diverse in its origin and may be distorted by late diagenesis. Holserab (1997) argued that under reducing conditions $\mathrm{Ce}^{3+}$ is adsorbed on $\mathrm{Fe}-\mathrm{Mn}$ oxyhydroxides or organic particulate matter and the remaining solution tends to show a negative Ce-anomaly, but any such primary record may be overprinted by late diagenetic alteration.

The REE patterns and elemental ratios in sediments are commonly used to predict depositional environment. For example, depletion of Ce relative to its neighbors associated with HREE enrichments, which are typical of seawater pattern, are considered strong indicators of an oxic depositional environment (Sarkar et al. 2003) attributed to open ocean environment and formation of authigenic minerals under oxic conditions (Kidder et al. 2003). The depletion in HREE associated with a bellshaped MREE pattern and slight Ce-depletion may indicate suboxic conditions (German et al. 1995, Morad \& Felitsyn 2001, Shields \& Stille 2001). In contrast, the lack of Ce depletion, or even excess $\mathrm{Ce}$, associated with LREE- to MREE-enriched patterns, would indicate anoxic conditions (Patrick et al. 2004, Ounis et al. 2008, Bright et al. 2009, Fadel et al. 2015). The Ce-anomalies in apatite have been used for the purpose of reconstruction of redox conditions; positive $\mathrm{Ce}$ anomalies in biogenic apatites have 
been considered to lend support to oceanic anoxia (Wright et al. 1987, Morad \& Felitsyn 2001). This is underscored by variations in $\mathrm{Ce} / \mathrm{La}$ ratios which may reflect oxygenpoor to oxygen-rich environment. For example, Ce/ La of $\sim 0.35$ and $\sim 0.78$ has been established for open seawater (Høgdahl et al. 1968) and marine upwelling-type phosphorites (Altstchuler 1980), respectively, while it is $\sim 2.0$ in average world shales (Haskin \& Haskin 1966). These interpretations, however, should be considered with caution when constructing paleoenvironmental models, because Ce concentrations may reflect solely the pore water anoxia (Kemp \& Trueman 2003). The redox mobilization of $\mathrm{Ce}$ in pore waters has been shown to be almost identical to its behavior in anoxic basins where high dissolved $\mathrm{Ce}^{3+}$ concentrations are expected in anoxic pore waters. The removal of dissolved Ce in pore water environments takes place by adsorptive scavenging and/or incorporation in rapidly settling large particles like fecal pellets (De Baar 1983).

The occurrence of phosphates in the Bohemian Cretaceous Basin was reported by many authors (Uličný et al. 1996, 1997; Žítt et al. 1998; Wiese et al. 2004; Vodrážka et al. 2009). However, the REE systematics in the Cenomanian and Turonian sedimentary sequences of the Bohemian Cretaceous Basin were rarely investigated. Uličný et al. (1997) reported on elevated concentrations of some REE in phosphorites relative to the coexisting marlstones and/or mudstones. Dobeš et al. (1987) have found similar REE enrichments in Turonian phosphorites of the Bohemian Cretaceous Basin and explained the observed enrichment by REE incorporation into apatite. However, a vertical stratigraphy profile of REE abundance and systematics across the Cenomanian-Turonian boundary in the Bohemian Cretaceous Basin has not yet been made.

Here, new REE-Y-U abundance data is presented for samples collected from the mudstones of the Pecínov Member of the late Cenomanian Peruc-Korycany Formation, the lowermost part of the Bílá Hora Formation (upper Cenomanian-lower Turonian), phosphate nodules, coprolites, sponges and tubular structures (burrows) from the Pecínov Member, Bílá Hora and Teplice formations, respectively, with the aim to (i) investigate the geochemical association and patterns of distribution of REE, and (ii) show their significance as indicators of source rocks and depositional environment with special emphasis on the phosphogenic processes and the anoxic event at the Cenomanian-Turonian boundary.

\section{Geological setting}

The Bohemian Cretaceous Basin (BCB) (CenomanianSantonian) is an intracontinental depositional depression that formed by the reactivation of a fault system

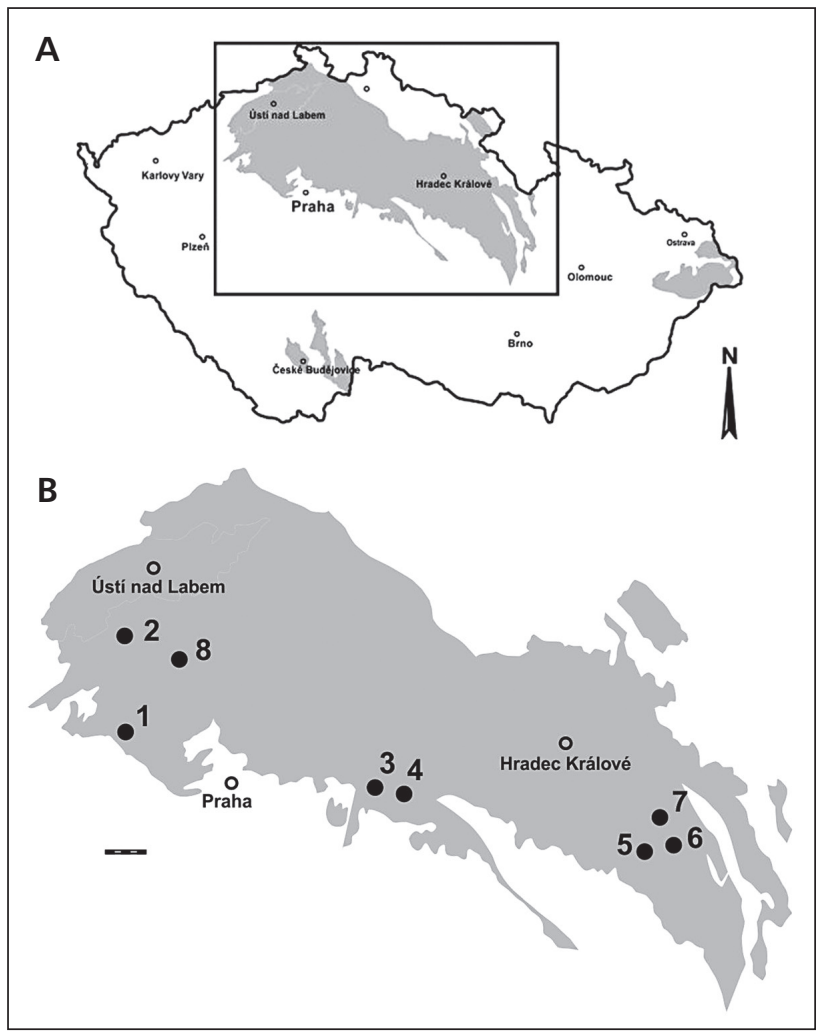

Figure 1. A - distribution of Cretaceous rocks (in gray) in the Czech Republic. - B - Bohemian Cretaceous Basin showing sampling sites: 1 - Pecínov quarry; 2 - Úpohlavy quarry; 3 - Plaňany quarry; 4 - Nová Ves quarry; 5 - Borehole RP-32; 6 - Borehole RP-40; 7 - Borehole 4270-01W; 8 - Borehole 4530-A.

in the Variscan basement of the Bohemian Massif in the mid-Cretaceous (Uličný 1997, 2001) and acted as a seaway between the North Sea and the Tethys Ocean. Sedimentation within the BCB began during the late Albian or the earliest Cenomanian (Valečka \& Skoček 1991), with displaced fault zones creating topographical lows adjacent to erosional source areas. The oldest sediments in the $\mathrm{BCB}$ are of fresh water origin and were deposited in the most depressed areas (Žítt et al. 1998). The Cenomanian-lower Turonian sequence is represented by the Peruc-Korycany Formation (Cenomanian) and the Bílá Hora Formation (uppermost Cenomanian-lower Turonian) (Čech et al. 2005, Košták et al. 2018). The Peruc-Korycany Formation consists of three members: Peruc, Korycany (Čech et al. 1980), and Pecínov (Uličný 1997). The upper Turonian sequence in the BCB is represented by the Jizera and Teplice formations (Čech et al. 1980, Wiesse et al. 2004).

The Pecínov Member at Pecínov quarry was subdivided by Uličný et al. (1997) and Košt'ák et al. (2018) into four principal units $\mathrm{P} 1-\mathrm{P} 4$, which are bounded by well-recognizable, erosional and/or burrowed surfaces. The sequence description has recently been updated by Košták et al. (2018). Unit P1 is placed at a major erosional 
surface, overlain by a poorly-sorted, silty to gravelly sandstone, with abundant charcoal clasts and, locally, oyster moulds. The main body of P1 is comprised of $1.2 \mathrm{~m}$ thick succession of silty to sandy, bioturbated mudstones. Unit P2 is marked at the base by a sharp surface overlain by a glauconite-rich sandy siltstone. This bed is then overlain by a succession of $1.9 \mathrm{~m}$ of bioturbated, silty mudstones showing an alternation of dark- and light-colored beds. The base of unit P3 is marked by a prominent white to pale gray mudstone layer resting on a burrowed surface. This layer is overlain by cyclic sedimentation marked by changes in the content of organic matter and fine-grained siliciclasts. Unit P4 rests on a sharp surface on top of P3. Its base is marked by a sharp contrast between the extensively burrowed glauconite-rich, gray, silty mudstone and the dark gray to black, clay-rich mudstone of the base of unit $\mathrm{P} 4$. At the top of P4, medium-grey bed is characterized by wide-spread bioturbation with pale grey infill and almost zero faunal and plant remains.

The Bílá Hora Formation at Pecínov quarry was described by Uličný et al. (1997). A more detailed description of the basal portion of the Bílá Hora Formation is presented by Košt'ák et al. (2018). Unit BH 1 is $0.6 \mathrm{~m}$ thick, comprised of strongly glauconitic, grain- to matrix-supported quartz siltstone that rests on a strongly bioturbated, irregular surface. The bioturbation reaches as much as $40 \mathrm{~cm}$ below the contact. This unit is considerably rich in phosphate nodules and clasts. The boundary between units $\mathrm{BH} 1$ and $\mathrm{BH} 2$ is developed as a burrowed, phosphatized erosive surface. Unit BH 2 is a gray, calcareous, glauconitic claystone to siltstone with sand admixture. Units BH 2 and BH 3 are separated by a thin, bioturbated level enriched in fine-grained quartz and glauconite sand. Unit BH 3 is a $60-70 \mathrm{~cm}$ thick succession of strongly bioturbated, gray marlstones with high content of fish bones and shark teeth. Oysters and brachiopods are present. Unit $\mathrm{BH} 4$ constitutes the main body of the Bílá Hora Formation at Pecínov quarry. The base of unit BH 4 is a strongly bioturbated, fossiliferous marlstone. It defines the base of a succession of rhythmically bedded, foraminiferal marlstones and clayey foraminiferal limestones.

At Plaňany quarry the Cretaceous sequence is comprised of Korycany Member of the Peruc-Korycany Formation and the Bílá Hora Formation. The sediments cover the weathered crystalline rock massif. The depth of weathering reaches 5 meters; burrows more than $80 \mathrm{~cm}$ deep are common on surface of these rocks. The base of the Bílá Hora Formation is represented here by reworked poorly sorted carbonate clasts, shell fragments, sponges, phosphoclasts, etc. Some clasts are coated or filled with glauconite (Žitt et al. 2010). The overlying unit is a friable glauconite sandstone bed, about $0.5 \mathrm{~m}$ thick, topped by a dark gray $0.3-0.5 \mathrm{~m}$ thick claystone bed.
At Úpohlavy quarry the upper Turonian sequence is comprised of $27 \mathrm{~m}$ thick marls, fossiliferous clayey limestone and marl/limestone alternations (Wiese et al. 2004). It consists of two sedimentary units; Jizera and Teplice Formation, respectively. Two coprolitic beds are recognized in the basal part of the Teplice Formation; the boundary between the Jizera and Teplice formations is taken at the Lower Coprolite Bed (Čech et al. 1996). It is $20-30 \mathrm{~cm}$ thick, glauconitic bed with mm-sized quartz grains and bioturbated phosphate clasts, overlying an erosive base and grading upward into dark marl. An Upper Coprolite Bed occurs overlying another erosive surface at the top of the dark marl (Wiese et al. 2004).

\section{Material and methods}

\section{Samples}

Most samples (see Fig. 1 for geographic location) for this study come from the upper part of Pecínov Member (unit $\mathrm{P} 3$; about $2 \mathrm{~m}$ thick and unit $\mathrm{P} 4$; about $1 \mathrm{~m}$ thick) and the lowermost part of the Bílá Hora Formation (unit BH 1; $0.6 \mathrm{~m}$ thick) exposed at Pecínov quarry (see Uličný et al. 1997 and Košt'ák et al. 2018 for units terminology and stratigraphic location), and the Lower Coprolite Bed of the Teplice Formation at Úpohlavy quarry (see Wiese et al. 2004 for stratigraphic location). Several samples were also collected from the basal part of the Bílá Hora Formation (Plaňany quarry), Teplice Formation (Nová Ves quarry and Býčkovice roadcut; Vodrážka et al. 2009). In addition, some samples from subsurface sections of drilled wells were also included. Sampling at Pecínov quarry covered the base of the $N$. juddii Zone at the base of unit P3 (sensu Košták et al. 2018), mid-Cenomanian, Pecínov Member, Peruc-Korycany Formation and the upper contact of the $N$. juddii Zone with the $W$. devonese Zone at unit BH 1 (sensu Košták et al. 2018), earliest Turonian, Bílá Hora Formation.

Subsurface. - Samples no. 1A \& 2: Glauconitic sandstone and siltstone, near upper contact of Pecínov Member with the Bílá Hora Formation, BH RP-40, depth $202.7 \mathrm{~m}$ and $\mathrm{BH} 4530-\mathrm{A}$, depth $81.8 \mathrm{~m}$ respectively. Samples no. 3A \& 4A: Glauconitic sandstone and siltstone, Bílá Hora Formation, near the lower contact with Pecínov Member, BH RP-32, depth $425.4 \mathrm{~m}$ and BH 4270-01W, depth $292.8 \mathrm{~m}$, respectively.

Pecinovquarry.-Samples no. 6A, 7A, 22, 23 \& 24A: Glauconitic grayish green mudstones, unit P3; Pecínov Member (samples from top to bottom at $40-50 \mathrm{~cm}$ interval). Samples no. 5A, 8A, 9A, 10A \& 11A: Glauconitic dark greenish gray mudstones, unit P4, Pecínov Member (samples from top to bottom at $c a .20 \mathrm{~cm}$ 


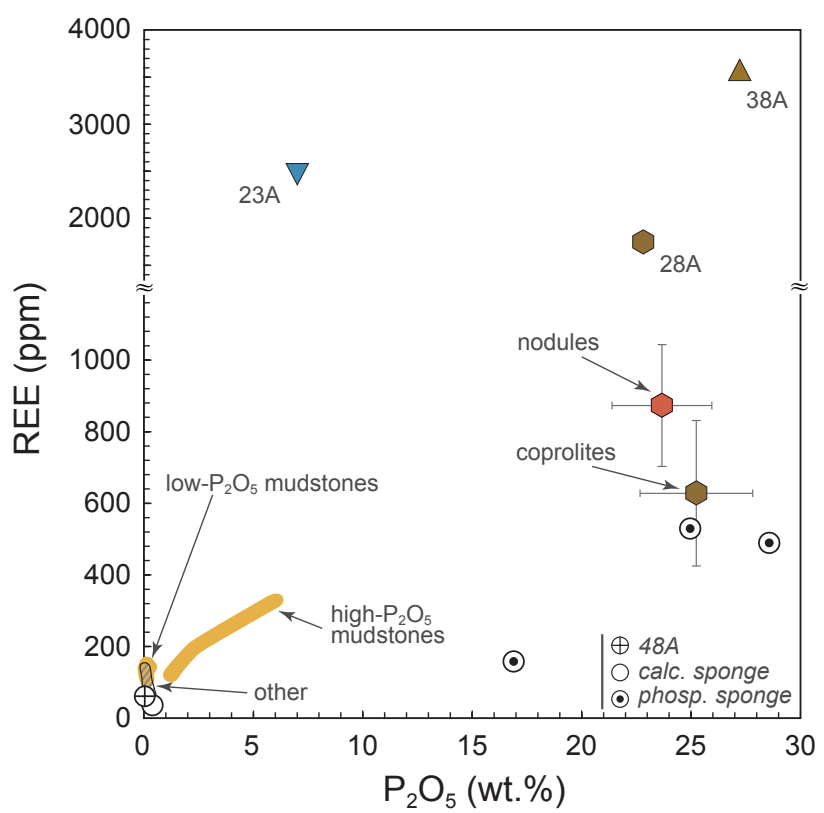

Figure 2. Sum REE vs. $\mathrm{P}_{2} \mathrm{O}_{5}$ contents in the analyzed samples. Mean values and one sigma uncertainty are plotted for coprolites (save for REE-rich sample 28A) and phosphate nodules. Mudstones with $<1.0$ wt $\%$ and $>1.0$ wt $\% \mathrm{P}_{2} \mathrm{O}_{5}$ are plotted as separate groups. The 'Other' group includes sandstones, siltstones, glauconite bed and kaolinitic claystone bed. Other samples are plotted individually.

intervals). Sample no. 23A: Phosphatic glauconitic silty tubular structure at the erosive and burrowed contact between unit P3 and unit P2, base of unit P3, Pecínov Member. Samples no. 12C, 13, 14, 16G, 17F, 18B, 19C \& 20E: Glauconitic, phosphatic greenish gray silty mudstones, unit BH 1, Bílá Hora Formation. Samples no. 13A, 14A, 15A, 16A, 17A, 17E, 18A and 19A: Phosphate nodules distributed in unit BH 1, Bílá Hora Formation. Sample no. 20A: Phosphate mold of bivalve, associated with phosphate nodules in unit BH 1, Bílá Hora Formation (unit numbers after Košt’ák et al. 2018).

Úpohlavy quarry. - Samples no. 28A, 30A, 31A, 39A \& 41C: Phosphate coprolites, Lower Coprolite Bed, Teplice Formation. Sample no. 38A: Phosphatic tube-fill, Base of Lower Coprolite Bed, Teplice Formation.

Plañany quarry. - Sample no. 42A: Calcareous sponge, base of the Bílá Hora Formation (eastern side of the quarry). Sample no. 48: Calcareous tubular structure, base of the Bílá Hora Formation (western side). Sample no. 50A: Glauconite bed overlying the clastic basal part of the Bílá Hora Formation (western side). Sample no. 51A: Dark gray claystone bed overlying the glauconite sandstone bed (western side).

Nová Ves quarry. - Sample no. 52A: Phosphatic sponge, base of the Bílá Hora Formation. Sample no. 52C:
Phosphatic limestone fragment, base of the Bílá Hora Formation.

Býčkovice roadcut. - Sample no. 53: Phosphatic sponge, Teplice Formation.

\section{Methods}

Petrology. - All samples were examined under the optical polarized microscope. Selected samples were analyzed by X-ray diffractometry (CGS laboratories); the powder $\mathrm{X}$-ray diffraction patterns of whole-rock samples were collected in the Bragg-Brentano geometry on a Bruker D8 Advance diffractometer, using $\mathrm{CuK \alpha}$ radiation and Lynx Eye XE detector.

Chemical analysis. - Samples were treated with concentrated $\mathrm{HF}$ and $\mathrm{HClO}_{4}$ and evaporated to dryness.
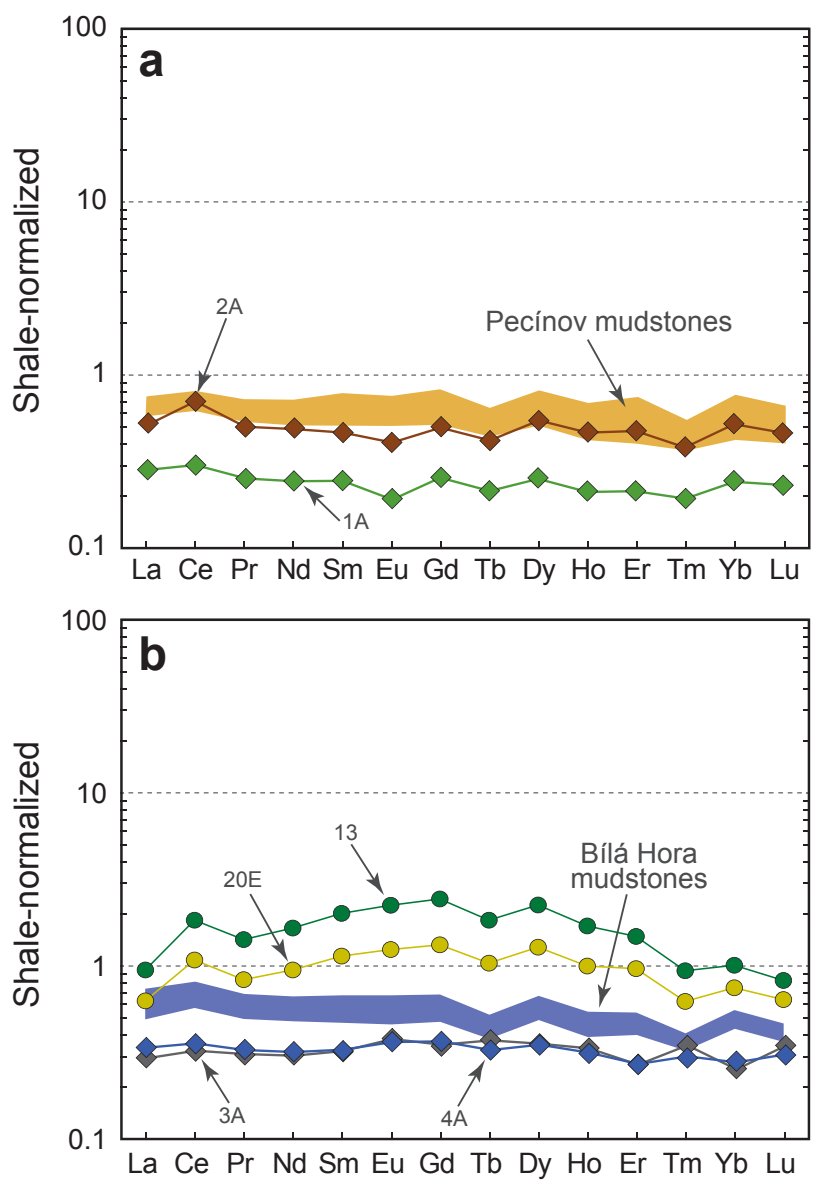

Figure 3. Shale-normalized REE distribution pattern of (A) Pecínov Member mudstones with sandstone and siltstone, and (B) Bílá Hora mudstones with sandstone and siltstone. Two REE-enriched Bílá Hora mudstones with a pronounced bell-shaped REE pattern are plotted individually $(13,20 \mathrm{E})$. 
Table 1. Rare earth elements, $\mathrm{P}_{2} \mathrm{O}_{5}, \mathrm{Y}$ and $\mathrm{U}$ concentrations, Ce-anomaly and significant ratios in the studied samples (sample description and location are outlined in the text).

\begin{tabular}{|c|c|c|c|c|c|c|c|c|c|c|c|c|c|c|}
\hline & 22 & 23 & $24 \mathrm{~A}$ & $6 \mathrm{~A}$ & $7 \mathrm{~A}$ & $8 \mathrm{~A}$ & $9 \mathrm{~A}$ & $10 \mathrm{~A}$ & $11 \mathrm{~A}$ & $5 \mathrm{~A}$ & $1 \mathrm{~A}$ & 2 & BHVO-2 & IC10D \\
\hline $\mathrm{La}$ & 26.5 & 29.0 & 30.9 & 27.5 & 24.9 & 24.2 & 25.2 & 27.3 & 27.6 & 23.9 & 11.4 & 21.0 & 14.8 & 410 \\
\hline $\mathrm{Ce}$ & 62.5 & 67.6 & 60.5 & 62.8 & 58.7 & 55.1 & 57.8 & 60.8 & 60.6 & 51.4 & 24.5 & 58.8 & 39.9 & 975 \\
\hline $\operatorname{Pr}$ & 6.6 & 7.0 & 7.4 & 6.7 & 6.0 & 5.6 & 6.0 & 6.3 & 6.3 & 5.5 & 2.5 & 4.9 & 5.26 & 115 \\
\hline $\mathrm{Nd}$ & 24.7 & 26.6 & 27.8 & 24.1 & 22.1 & 20.6 & 21.7 & 22.6 & 23.1 & 19.7 & 9.1 & 18.4 & 24.2 & 476 \\
\hline $\mathrm{Sm}$ & 5.2 & 5.5 & 5.9 & 4.9 & 4.5 & 4.1 & 4.3 & 4.3 & 4.5 & 3.9 & 1.8 & 3.4 & 6.10 & 84.8 \\
\hline $\mathrm{Eu}$ & 0.94 & 1.2 & 1.2 & 1.0 & 0.90 & 0.87 & 0.82 & 0.95 & 0.97 & 0.88 & 0.30 & 0.65 & 2.05 & 21.9 \\
\hline $\mathrm{Gd}$ & 4.6 & 5.0 & 5.3 & 4.7 & 4.2 & 3.6 & 3.7 & 3.8 & 3.8 & 3.3 & 1.6 & 3.1 & 6.25 & 69.2 \\
\hline $\mathrm{Tb}$ & 0.71 & 0.79 & 0.78 & 0.78 & 0.71 & 0.6 & 0.59 & 0.59 & 0.56 & 0.54 & 0.26 & 0.50 & 0.95 & 7.5 \\
\hline Dy & 4.4 & 4.5 & 4.5 & 4.4 & 4.1 & 3.3 & 3.5 & 3.3 & 3.1 & 2.8 & 1.4 & 3.0 & 5.25 & 33.2 \\
\hline Ho & 0.87 & 0.92 & 0.8 & 0.91 & 0.86 & 0.70 & 0.71 & 0.64 & 0.59 & 0.57 & 0.28 & 0.62 & 0.99 & 4.8 \\
\hline $\mathrm{Er}$ & 2.6 & 2.8 & 2.2 & 2.5 & 2.4 & 1.9 & 2.0 & 1.7 & 1.7 & 1.5 & 0.8 & 1.8 & 2.51 & 10.1 \\
\hline $\mathrm{Tm}$ & 0.34 & 0.35 & 0.26 & 0.36 & 0.34 & 0.26 & 0.28 & 0.25 & 0.23 & 0.24 & 0.12 & 0.23 & 0.32 & 0.92 \\
\hline $\mathrm{Yb}$ & 2.8 & 2.6 & 2.0 & 2.4 & 2.3 & 1.8 & 2.0 & 1.8 & 1.7 & 1.5 & 0.84 & 1.9 & 2.01 & 5.4 \\
\hline $\mathrm{Lu}$ & 0.41 & 0.39 & 0.28 & 0.39 & 0.37 & 0.28 & 0.3 & 0.26 & 0.25 & 0.25 & 0.14 & 0.28 & 0.30 & 0.66 \\
\hline$\Sigma$ REE & 142.93 & 154.12 & 149.76 & 143.34 & 132.42 & 123.01 & 128.64 & 134.5 & 135 & 115.89 & 55.04 & 118.5 & & \\
\hline $\mathrm{Y}$ & 23.4 & 24.8 & 19.4 & 25.4 & 24.4 & 19.5 & 20.3 & 18.1 & 15.9 & 14.2 & 7.7 & 15.8 & 25.2 & 113 \\
\hline $\mathrm{U}$ & 11.0 & 3.4 & 3.9 & 3.2 & 3.3 & 2.6 & 2.7 & 2.7 & 2.7 & 2.5 & 1.6 & 2.4 & 16.7 & 15.8 \\
\hline $\mathrm{P}_{2} \mathrm{O}_{5}(\%)$ & 0.27 & 0.14 & 0.08 & 0.05 & 0.14 & 0.07 & 0.08 & 0.08 & 0.07 & 0.09 & 0.15 & 0.03 & & \\
\hline$\Sigma \mathrm{REE} / \mathrm{P}_{2} \mathrm{O}_{5} \times 100$ & 5.37 & 11.01 & 17.83 & 31.16 & 9.39 & 17.08 & 15.88 & 17.93 & 18.75 & 13.63 & 3.64 & 34.85 & & \\
\hline $\boldsymbol{\Sigma} \mathrm{REE} / \mathrm{Y}$ & 6.1 & 6.22 & 7.71 & 5.65 & 5.43 & 6.3 & 6.35 & 7.45 & 8.47 & 8.16 & 7.13 & 7.49 & & \\
\hline $\boldsymbol{\Sigma} \mathrm{REE} / \mathrm{U}$ & 12.96 & 50.7 & 38.1 & 44.79 & 40.62 & 48.05 & 47.12 & 49.45 & 49.63 & 45.63 & 35.28 & 48.97 & & \\
\hline $\mathrm{Ce} / \mathrm{La}$ & 2.36 & 2.33 & 1.96 & 2.28 & 2.35 & 2.27 & 2.29 & 2.23 & 2.19 & 2.15 & 2.15 & 2.81 & & \\
\hline $\mathrm{La}_{\mathrm{N}} / \mathrm{Yb}_{\mathrm{N}}$ & 0.83 & 0.96 & 1.34 & 0.99 & 0.92 & 1.13 & 1.09 & 1.34 & 1.4 & 1.38 & 1.17 & 0.98 & & \\
\hline Ce-anomaly & 0.07 & 0.06 & -0.01 & 0.06 & 0.07 & 0.06 & 0.07 & 0.04 & 0.05 & 0.04 & 0.04 & 0.08 & & \\
\hline
\end{tabular}

Lithium metaborate $\left(\mathrm{Li}_{2} \mathrm{~B}_{4} \mathrm{O}_{7}\right)$ and $\mathrm{Na}_{2} \mathrm{CO}_{3}(1: 1)$ were added to dried residues and the mixture was fused in Pt beakers at $1050^{\circ} \mathrm{C}$. The resulting material was finally dissolved in $7 \mathrm{M} \mathrm{HNO}_{3}$. Trace element concentrations were measured using an Agilent 7900x ICPMS, housed at the Czech Geological Survey. Basalt BHVO-2 (USGS) and REE-rich phosphate sample IC10D (Ackerman et al. 2017) were measured for monitoring the instrumental bias and assessing the quality control. The results for BHVO-2 and IC10D are listed in Table 1 and are within the ranges reported by Jochum et al. (2005) and Ackerman et al. (2017), respectively.

Data processing. - REE data were normalized to average world shale of Piper (1974) based on values of Haskin \& Haskin (1966). REE in main groups of samples were normalized to CI chondrite of Anders \& Grevesse (1989) and compared to REE contents in average granite (Taylor \& McLennan 1985), basalt (Frey \& Haskin 1964), shale (Haskin \& Haskin 1966) and seawater (Høgdahl et al.
1968). The Ce-anomaly was calculated according to Wright et al. (1987) as: $\log \left[3 \times \mathrm{Ce}_{\mathrm{N}} /\left(2 \times \mathrm{La}_{\mathrm{N}}+\mathrm{Nd}_{\mathrm{N}}\right)\right]$, where normalizing values were those of the North American Shale Composite (NASC) of Haskin \& Haskin (1966). Significant ratios of REE to $\mathrm{P}_{2} \mathrm{O}_{5}, \mathrm{Y}$ and $\mathrm{U}$ were calculated for all samples together with $\mathrm{Ce} / \mathrm{La}$ ratio and $\mathrm{La} / \mathrm{Yb}$ ratio of NASC-normalized values. Statistical processing of analytical data was performed to extract correlation coefficients, using Spearman method, and factor analysis, using Principal Component Analysis (PCA) Varimax Rotation method.

\section{Results}

\section{Petrographic description}

Samples of Pecínov Member (units P3 and P4 at Pecínov quarry) are dark gray to black silty to sandy mudstones, rich in quartz and glauconite with occasional sand-size 
Table 2. Rare earth elements, $\mathrm{P}_{2} \mathrm{O}_{5}, \mathrm{Y}$ and $\mathrm{U}$ concentrations, Ce-anomaly and significant ratios in the studied samples from the Bílá Hora Formation (unit $\mathrm{BH} 1$; sample description and location are outlined in the text).

\begin{tabular}{|c|c|c|c|c|c|c|c|c|c|c|}
\hline & $12 \mathrm{C}$ & 13 & 14 & $16 \mathrm{G}$ & $17 \mathrm{~F}$ & $18 \mathrm{~B}$ & $19 \mathrm{C}$ & $20 \mathrm{E}$ & $3 \mathrm{~A}$ & $4 \mathrm{~A}$ \\
\hline $\mathrm{La}$ & 21.9 & 38.7 & 20.2 & 24.7 & 22.5 & 28.8 & 30.2 & 25.7 & 12.0 & 13.8 \\
\hline $\mathrm{Ce}$ & 47.6 & 152.1 & 54.2 & 55.5 & 51.6 & 62.2 & 66.9 & 89.3 & 27.0 & 29.7 \\
\hline $\operatorname{Pr}$ & 5.0 & 14.3 & 5.5 & 5.7 & 5.3 & 6.5 & 7.0 & 8.4 & 3.1 & 3.3 \\
\hline $\mathrm{Nd}$ & 18.4 & 62.7 & 21.5 & 20.8 & 19.8 & 23.8 & 25.4 & 35.9 & 11.5 & 12.1 \\
\hline $\mathrm{Sm}$ & 3.5 & 15.1 & 4.6 & 4.0 & 4.0 & 4.8 & 5.1 & 8.5 & 2.4 & 2.5 \\
\hline $\mathrm{Eu}$ & 0.74 & 3.6 & 0.90 & 0.91 & 0.86 & 1.0 & 1.1 & 2.0 & 0.61 & 0.59 \\
\hline Gd & 3.0 & 15.4 & 4.4 & 3.6 & 3.5 & 4.0 & 4.3 & 8.4 & 2.2 & 2.3 \\
\hline $\mathrm{Tb}$ & 0.46 & 2.3 & 0.64 & 0.52 & 0.54 & 0.6 & 0.61 & 1.3 & 0.46 & 0.40 \\
\hline Dy & 2.7 & 12.3 & 3.7 & 2.9 & 3.0 & 3.4 & 3.6 & 7.0 & 2.0 & 1.9 \\
\hline Но & 0.52 & 2.3 & 0.72 & 0.57 & 0.6 & 0.66 & 0.66 & 1.3 & 0.45 & 0.42 \\
\hline Er & 1.5 & 5.5 & 2.0 & 1.6 & 1.7 & 1.9 & 1.9 & 3.6 & 1.0 & 1.0 \\
\hline $\mathrm{Tm}$ & 0.20 & 0.59 & 0.26 & 0.21 & 0.22 & 0.25 & 0.25 & 0.39 & 0.22 & 0.19 \\
\hline $\mathrm{Yb}$ & 1.6 & 3.6 & 1.9 & 1.5 & 1.7 & 1.8 & 1.8 & 2.6 & 0.89 & 0.98 \\
\hline $\mathrm{Lu}$ & 0.23 & 0.5 & 0.28 & 0.22 & 0.24 & 0.26 & 0.27 & 0.39 & 0.21 & 0.19 \\
\hline$\Sigma$ REE & 107.36 & 328.98 & 120.71 & 122.68 & 115.67 & 140.01 & 149.03 & 194.88 & 64.12 & 69.44 \\
\hline Y & 14.2 & 70.4 & 21.0 & 15.0 & 15.5 & 17.4 & 17.7 & 38.8 & 11.5 & 11.4 \\
\hline U & 2.5 & 13.5 & 37.1 & 2.7 & 2.6 & 2.2 & 3.0 & 7.1 & 1.3 & 1.1 \\
\hline $\mathrm{P}_{2} \mathrm{O}_{5}(\%)$ & 0.12 & 6.0 & 1.2 & 0.15 & 0.15 & 0.16 & 0.12 & 2.3 & 0.32 & 0.22 \\
\hline$\Sigma \mathrm{REE} / \mathrm{P}_{2} \mathrm{O}_{5} \times 100$ & 8.73 & 0.55 & 0.98 & 8.29 & 7.82 & 8.86 & 12.42 & 0.85 & 2.02 & 3.16 \\
\hline$\Sigma \mathrm{REE} / \mathrm{Y}$ & 7.58 & 4.67 & 5.75 & 8.16 & 7.47 & 8.07 & 8.44 & 5.03 & 5.56 & 6.09 \\
\hline$\Sigma \mathrm{REE} / \mathrm{U}$ & 43.12 & 24.33 & 3.25 & 46.12 & 44.83 & 63.07 & 49.68 & 27.49 & 49.71 & 61.45 \\
\hline $\mathrm{Ce} / \mathrm{La}$ & 2.17 & 3.93 & 2.68 & 2.25 & 2.29 & 2.16 & 2.21 & 3.48 & 2.24 & 2.15 \\
\hline $\mathrm{La}_{\mathrm{N}} / \mathrm{Yb}_{\mathrm{N}}$ & 1.2 & 0.93 & 0.89 & 1.36 & 1.12 & 1.43 & 1.42 & 0.84 & 1.16 & 1.29 \\
\hline Ce-anomaly & 0.05 & 0.19 & 0.1 & 0.06 & 0.06 & 0.05 & 0.05 & 0.17 & 0.04 & 0.03 \\
\hline
\end{tabular}

phosphate clasts. They are devoid of carbonates and when present they are merely reworked intraclasts. Pyrite nodules and pyritized bivalve shells are common. In the studied subsurface sections the mudstones are sandier; sand-size quartz and rock fragments constitute most of the framework together with glauconite pellets. The matrix consists mainly of clay minerals and organic matter.

The samples of the Bílá Hora Formation (unit BH 1 at Pecínov quarry) consist of gray glauconitic quartz siltstone and silty mudstones rich in organic matter and contain exotic brown phosphate nodules, several centimeters in size, rich in organic residues and pyrite. In subsurface sections this unit is more sandy and glauconitic with plenty of sand-size phosphate clasts. At Plaňany quarry, the basal part of the Bílá Hora Formation consists of reworked and brecciated calcareous and phosphatic poorly sorted friable clasts with abundant phosphatic sponges and rock fragments of metamorphic origin.

At Úpohlavy quarry, the coprolite samples, collected from the Lower Coprolite Bed, are brown, cylindrical with spindle shape, possessing typical shark morphology. They are embedded in dark gray marl and limestone, rich in benthic, planktonic and nektonic fauna. The coprolites are rich in organic matter and pyrite, but devoid of any carbonates.

\section{X-ray diffraction analysis}

The mineralogy of the mudstones in the Pecínov Member and the Bíla Hora Formation is dominated by quartz, glauconite and kaolinite. Minor amounts of apatite, pyrite, smectite and feldspar are present. The phosphate nodules, coprolites and sponges are dominated by carbonatefluorapatite with minor amounts of glauconite, quartz and pyrite. Calcite was detected in the coprolites samples, as impurities from host rocks attached to the outer surface only. At Plaňany quarry, the dark gray claystone bed is dominated by kaolinite whereas the underlying sandstone bed is dominated by glauconite. 

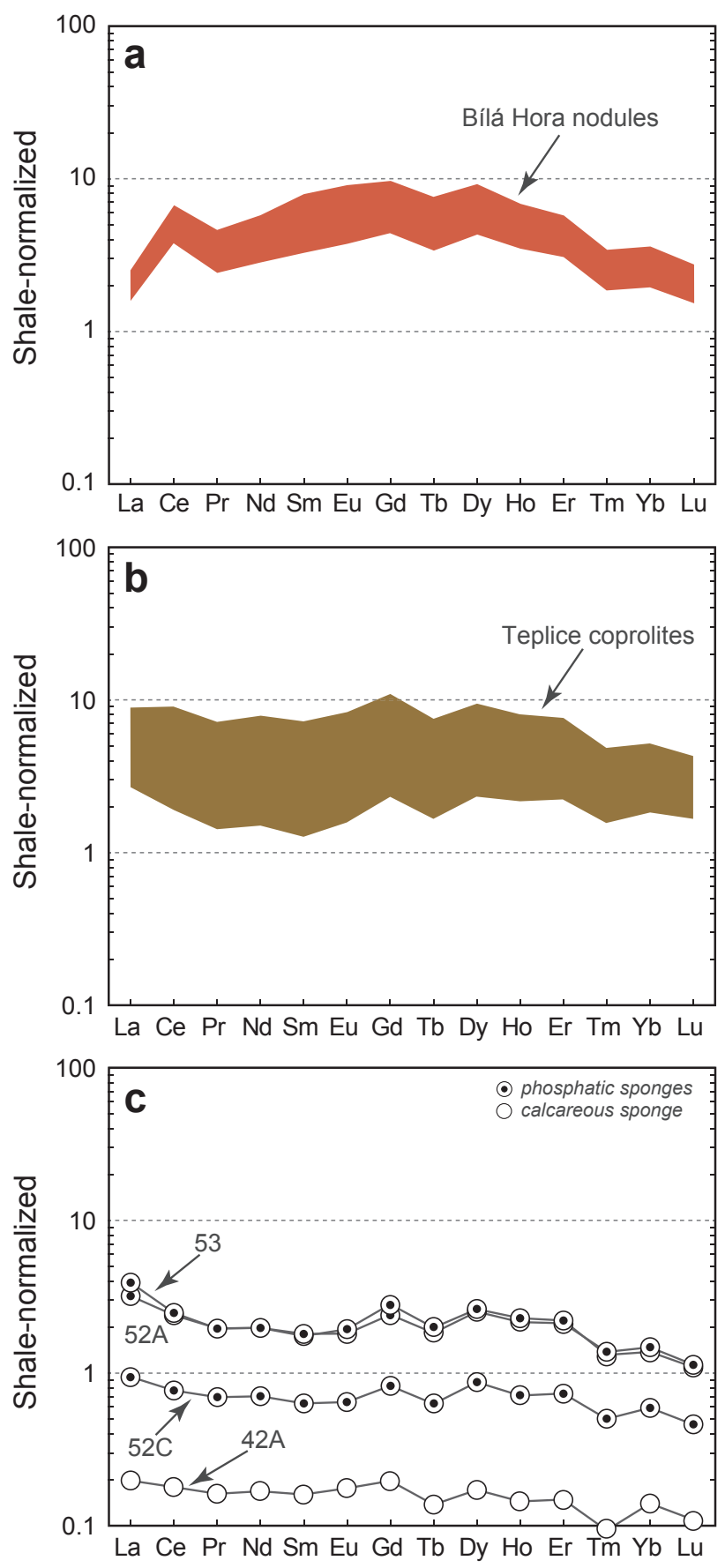

Figure 4. Shale-normalized REE distribution pattern of (A) Bílá Hora phosphate nodules, (B) Teplice Formation coprolites, and (C) calcareous and phosphate sponges. Note a pronounced $\mathrm{Tb}$ depletion in all samples.

\section{Chemical analysis}

The results of chemical analysis are listed in Tables 1-5. The samples show a range of total REE contents from 35 to $3,544 \mathrm{ppm}$. The lowest concentrations are found in the sandstones (subsurface sections) while the highest $\Sigma$ REE

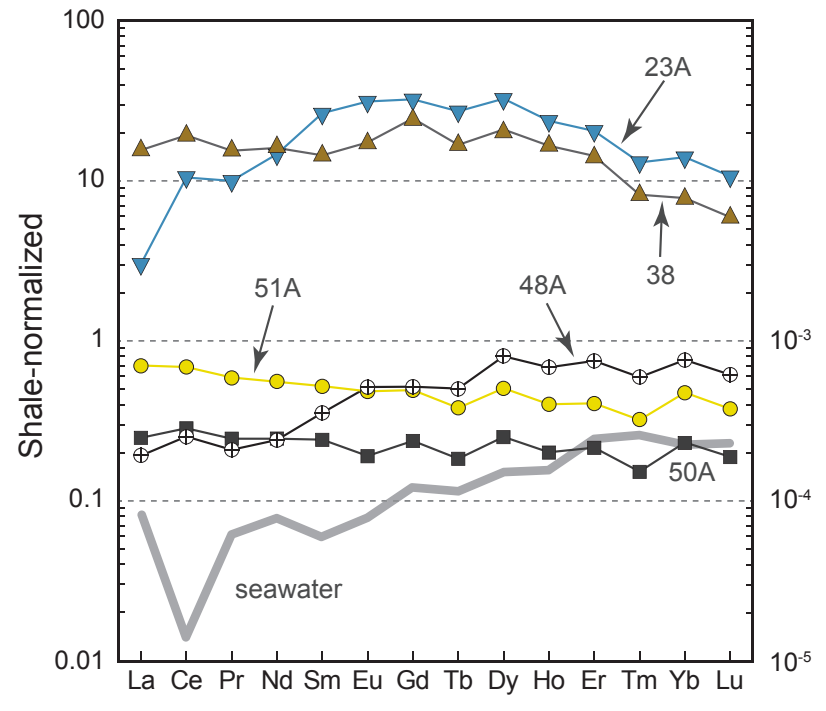

Figure 5. Shale-normalized REE distribution patterns of phosphate tube-fill samples $(23 \mathrm{~A}, 38)$ and other samples from Plaňany quarry. Seawater REE pattern is plotted for comparison; see secondary y axis for values (REE concentrations are taken from Høgdahl et al. 1968).

were measured for the phosphatic tube-fills (Fig. 2). The non-phosphatic mudstones of Pecínov Member (units P3 and P4) and Bílá Hora (unit BH 1) have relatively low $\Sigma$ REE concentrations of $107-154 \mathrm{ppm}$ which is lower than the $\Sigma$ REE $=204 \mathrm{ppm}$ for average shale of Haskin \& Haskin (1966). The phosphate-rich components (nodules, coprolites, molds, sponges and tubular structures) are REE-enriched relative to their corresponding host rocks in the Pecínov, Bílá Hora and Teplice rock units. The nodules have a mean content of 897 ppm REE (631-1,133 ppm), and the coprolites contain on average 851 ppm REE (399$1,748 \mathrm{ppm})$. Tube-fills have the highest concentrations of REE; a phosphate tube-fill sample 38 in the Teplice Formation contains 3,544 ppm and apatite-bearing tube-fill sample 23A in Pecínov Member has 2,496 ppm REE. Two phosphate sponges, sample 52A (Bílá Hora Formation) and sample 53 (Teplice Formation), contain 490 and 528 ppm $\Sigma$ REE, respectively, compared to $\Sigma \mathrm{REE}=36 \mathrm{ppm}$ in non-phosphatic sponge sample 42A (Bílá Hora Formation). A phosphatized bivalve mold sample 20A has $\Sigma$ REE $=682 \mathrm{ppm}$.

The glauconitic mudstones of Pecínov Member and the Bílá Hora Formation have low $\mathrm{P}_{2} \mathrm{O}_{5}$ contents, ranging from 0.03 to $0.27 \mathrm{wt} \%$ in the former and 0.12 to $6.0 \mathrm{wt} \%$ in the latter. Unit P3 of Pecínov Member has a mean $\mathrm{P}_{2} \mathrm{O}_{5}$ content roughly twice that of Unit P4. The highest $\mathrm{P}_{2} \mathrm{O}_{5}$ contents are found in the nodules, sponges and bivalve mold of the Bílá Hora Formation (19.6-26.5 wt \%) and the coprolites of the Teplice Formation (22.8-28.4 wt \%). The tube-fills show highly variable $\mathrm{P}_{2} \mathrm{O}_{5}$ content $(0.38-28.5$ wt \%) (Fig. 2). 


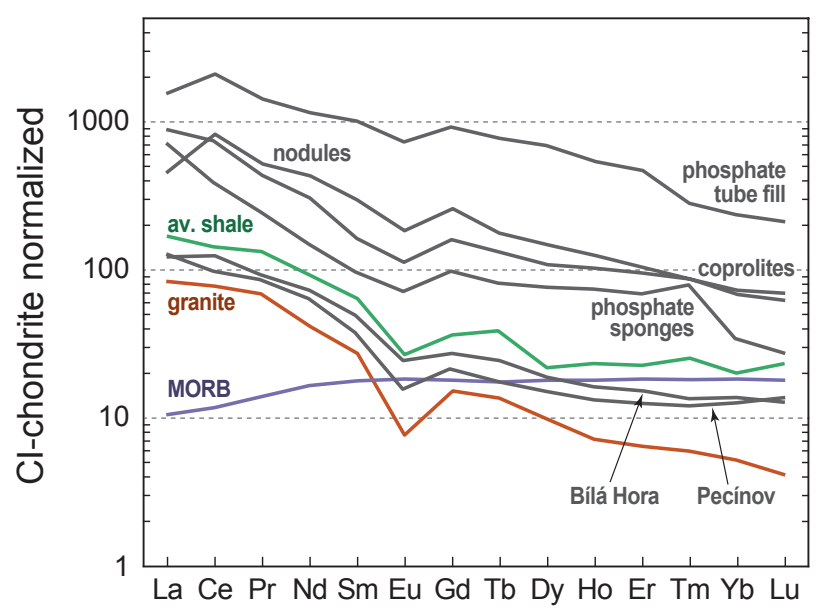

Figure 6. CI chondrite-normalized (Anders \& Grevesse 1989) REE patterns of major sample groups compared to those of average granite (Taylor \& McLennan 1985), average mid-ocean ridge basalt (MORB) (Frey \& Haskin 1964) and average shale (Haskin \& Haskin 1966).

Yttrium and U, like REE, generally follow phosphorus in their behavior with some exceptions (Tabs 1-4). They are low in the mudstones of Pecínov Member and the Bílá Hora Formation; ranging 7.7-24.4 ppm Y and 1.6-11.0 $\mathrm{ppm} \mathrm{U}$ in the former, and from 11.4 to $70.4 \mathrm{ppm} \mathrm{Y}$ and 1.1 to $37.1 \mathrm{ppm} \mathrm{U}$ in the latter. Unit P3 of Pecínov Member has higher $\mathrm{Y}$ and $\mathrm{U}$ concentrations than unit $\mathrm{P} 4$ and the Bílá Hora samples with $>1$ wt $\% \mathrm{P}_{2} \mathrm{O}_{5}$ contain up to six times more $\mathrm{Y}$ than those with $<1$ wt $\% \mathrm{P}_{2} \mathrm{O}_{5}$ (Table 5). Much higher $\mathrm{Y}$ and $\mathrm{U}$ concentrations are found in the nodules (173-269 ppm Y and 19.5-37.1 ppm U) and coprolites (152-476 ppm Y and 26.8-31.5 ppm U). Sponges show variable concentrations of $\mathrm{Y}$ and $\mathrm{U}$, generally following phosphorus have, whereby the highest $U$ content was measured in a phosphatic sponge sample 52A (43.3 ppm). On the other hand, the highest $\mathrm{Y}$ contents were found in tube-fill samples 23A and 38A (864 and $871 \mathrm{ppm}$, respectively). These anomalous $\mathrm{Y}$ concentrations are associated with the highest REE contents of 2,496 ppm and 3,545 ppm, respectively, but not with $\mathrm{U}$ contents, which exhibit an intermediate concentration range (0.69-28.2 ppm). Low Y and U concentrations are found in the glauconite and claystone beds of the Bílá Hora Formation (Plaňany quarry), approaching those in the Bílá Hora Formation samples at Pecínov quarry.

The sums of shale-normalized LREE values ( $\mathrm{La}, \mathrm{Ce}$, Pr, Nd, Sm), MREE (Eu, Gd, Tb, Dy) and HREE (Ho, Er, $\mathrm{Tm}, \mathrm{Yb}, \mathrm{Lu}$ ) were calculated to detect possible MREE enrichments (Tab. 5). The results show significant MREE enrichments in the mudstones of the Bílá Hora Formation containing $>1.0 \mathrm{wt} \% \mathrm{P}_{2} \mathrm{O}_{5}$, as well as in the phosphate nodules, phosphate coprolites, and phosphatic tube-fills. A slight enrichment of MREE is noticed in Unit P3 of the Pecínov Member, but none has been revealed in Unit P4
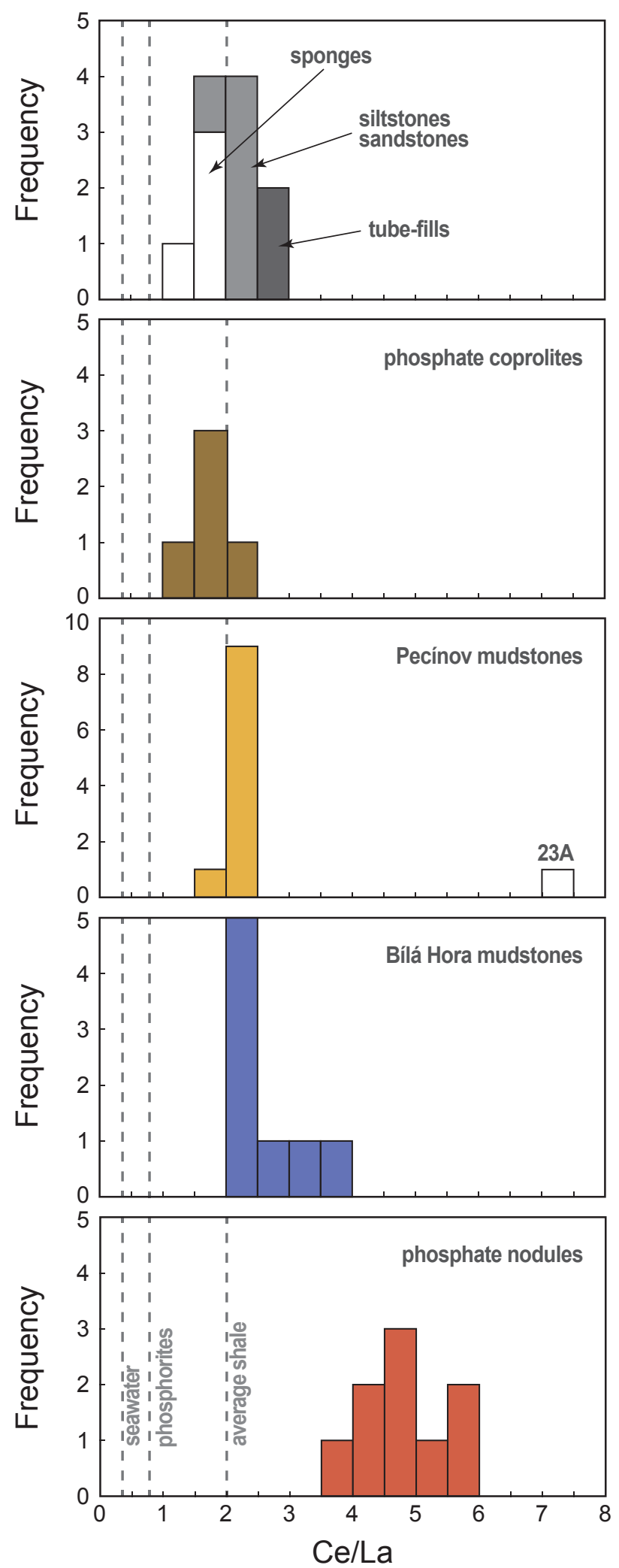

Figure 7. Frequency distribution plot of $\mathrm{Ce} / \mathrm{La}$ ratios in individual sample groups and some individual samples compared to average shale (Haskin \& Haskin 1966), average upwelling marine phosphorites (Altschuler 1980) and seawater (Høgdahl et al. 1968). 
Table 3. Rare earth elements, $\mathrm{P}_{2} \mathrm{O}_{5}$, Y and U concentrations, Ce-anomaly and significant ratios in phosphate nodules and bivalve mold (unit BH 1, Bílá Hora Formation; sample description and location are outlined in the text).

\begin{tabular}{|c|c|c|c|c|c|c|c|c|c|}
\hline & $13 \mathrm{~A}$ & $14 \mathrm{~A}$ & $15 \mathrm{~A}$ & $16 \mathrm{~A}$ & $17 \mathrm{~A}$ & $17 \mathrm{E}$ & $18 \mathrm{~A}$ & $19 \mathrm{~A}$ & $20 \mathrm{~A}$ \\
\hline $\mathrm{La}$ & 93.6 & 87.3 & 79.7 & 87.3 & 93.5 & 74.0 & 87.8 & 102 & 66.0 \\
\hline $\mathrm{Ce}$ & 413 & 392 & 309 & 485 & 540 & 377 & 409 & 499 & 322 \\
\hline $\operatorname{Pr}$ & 36.4 & 33.0 & 24.4 & 40.4 & 45.8 & 32.4 & 33.8 & 42.9 & 27.9 \\
\hline $\mathrm{Nd}$ & 165 & 147 & 107 & 191 & 216 & 150 & 154 & 199 & 128 \\
\hline $\mathrm{Sm}$ & 39.7 & 34.9 & 24.2 & 52.1 & 58.2 & 39.9 & 38.0 & 52.3 & 33.6 \\
\hline $\mathrm{Eu}$ & 9.7 & 8.7 & 6.0 & 13.0 & 14.3 & 9.7 & 9.5 & 12.9 & 8.3 \\
\hline Gd & 41.5 & 38.4 & 28.0 & 55.2 & 60.2 & 40.8 & 41.6 & 55.1 & 34.2 \\
\hline $\mathrm{Tb}$ & 6.0 & 5.7 & 4.1 & 8.5 & 9.2 & 6.3 & 6.3 & 8.3 & 5.2 \\
\hline Dy & 33.0 & 31.8 & 23.8 & 46.1 & 50.0 & 33.9 & 35.2 & 46.3 & 28.8 \\
\hline Ho & 6.0 & 6.0 & 4.7 & 8.5 & 9.0 & 6.2 & 6.6 & 8.6 & 5.3 \\
\hline $\mathrm{Er}$ & 14.2 & 14.5 & 11.6 & 20.2 & 21.2 & 14.9 & 16.0 & 20.9 & 12.8 \\
\hline $\mathrm{Tm}$ & 1.4 & 1.5 & 1.2 & 2.0 & 2.1 & 1.5 & 1.7 & 2.1 & 1.3 \\
\hline $\mathrm{Yb}$ & 7.8 & 8.4 & 6.8 & 12.0 & 12.1 & 9.1 & 9.4 & 12.5 & 7.4 \\
\hline $\mathrm{Lu}$ & 1.0 & 1.1 & 0.93 & 1.6 & 1.6 & 1.2 & 1.3 & 1.7 & 1.0 \\
\hline $\boldsymbol{\Sigma}$ REE & 868.06 & 810.56 & 631.16 & 1022.69 & 1132.7 & 796.56 & 849.9 & 1063.46 & 681.91 \\
\hline $\mathrm{Y}$ & 200 & 198 & 178 & 261 & 269 & 173 & 209 & 267 & 159 \\
\hline $\mathrm{U}$ & 37.1 & 32.7 & 26.7 & 21.8 & 19.5 & 27.9 & 28.7 & 34.7 & 38.0 \\
\hline $\mathrm{P}_{2} \mathrm{O}_{5}(\%)$ & 23.0 & 23.2 & 26.5 & 25.9 & 26.1 & 19.6 & 23.2 & 24.2 & 21.4 \\
\hline$\Sigma \mathrm{REE} / \mathrm{P}_{2} \mathrm{O}_{5} \times 100$ & 0.38 & 0.35 & 0.24 & 0.39 & 0.43 & 0.41 & 0.37 & 0.44 & 0.32 \\
\hline $\boldsymbol{\Sigma} \mathrm{REE} / \mathrm{Y}$ & 4.33 & 4.09 & 3.56 & 3.92 & 4.22 & 4.61 & 4.07 & 3.98 & 4.3 \\
\hline $\boldsymbol{\Sigma} \mathrm{REE} / \mathrm{U}$ & 23.39 & 24.81 & 23.63 & 47.02 & 58.06 & 28.58 & 29.6 & 30.69 & 17.97 \\
\hline $\mathrm{Ce} / \mathrm{La}$ & 4.42 & 4.5 & 3.88 & 5.55 & 5.78 & 5.09 & 4.66 & 4.88 & 4.87 \\
\hline $\mathrm{La}_{\mathrm{N}} / \mathrm{Yb}_{\mathrm{N}}$ & 1.03 & 0.89 & 1.01 & 0.63 & 0.67 & 0.7 & 0.8 & 0.7 & 0.77 \\
\hline Ce-anomaly & 0.23 & 0.24 & 0.22 & 0.28 & 0.28 & 0.26 & 0.25 & 0.25 & 0.25 \\
\hline
\end{tabular}

mudstones of the Bílá Hora Formation containing $<1.0$ wt $\% \mathrm{P}_{2} \mathrm{O}_{5}$, sponges, glauconite sandstone, and claystone beds.

\section{Distribution patterns}

The shale-normalized (Haskin \& Haskin 1966) REE patterns are plotted in Figures 3-5 and compared to average seawater of Høgdahl et al. (1968). All samples are enriched in LREE (except sample 48A). The phosphate components show pronounced enrichments in LREE, a typical "bell-shape" in the MREE and a well-developed positive Ce-anomaly. The samples of the Pecínov Member and the Bílá Hora Formation show less pronounced or absent Ce-anomaly and generally semi-flat patterns with relative LREE enrichments (Fig. 3).

The chondrite-normalized patterns of main groups of samples including mudstones of Pecínov Member and the Bílá Hora Formation, phosphate nodules and coprolites, phosphatic sponges and tube-fill show a consistent decrease in the HREE values, paralleled by a pronounced Eu depletion (Fig. 6). All patterns generally resemble that of granite and average world shale with some variations.

\section{Geochemical ratios}

The REE $/ \mathrm{P}_{2} \mathrm{O}_{5}$ (the values hereafter expressed as REE/ $\left.\mathrm{P}_{2} \mathrm{O}_{5} \times 100\right)$ may reflect contact duration between phosphate components and seawater (Wright et al. 1987); higher ratios may reflect longer contact time with seawater. The REE $/ \mathrm{P}_{2} \mathrm{O}_{5}$ ratios are more uniform in the phosphate nodules than in the coprolites $(0.24-0.44$, mean 0.38 ; versus $0.14-0.77$, mean 0.34 ), respectively. The tube-fills (samples $23 \mathrm{~A}$ and $38 \mathrm{~A}$ ) show $\mathrm{REE} / \mathrm{P}_{2} \mathrm{O}_{5}$ ratios of 3.57 and 1.30 , respectively. In the phosphate sponges $\mathrm{REE} / \mathrm{P}_{2} \mathrm{O}_{5}$ ranges from 0.17 to 0.21 . Other geochemical ratios were also calculated to show the variation in $\mathrm{U}$ and $\mathrm{Y}$ concentrations relative to REE (Tabs 1-5). 
Table 4. Rare earth elements, $\mathrm{P}_{2} \mathrm{O}_{5}, \mathrm{Y}$ and $\mathrm{U}$ concentrations, Ce-anomaly and significant ratios in phosphate coprolites (Teplice Formation), tube-fills, sponges and other samples (sample description and location are outlined in the text).

\begin{tabular}{|c|c|c|c|c|c|c|c|c|c|c|c|c|c|c|}
\hline & $28 \mathrm{~A}$ & $30 \mathrm{~A}$ & $31 \mathrm{~A}$ & $39 \mathrm{~A}$ & $41 \mathrm{C}$ & $42 \mathrm{~A}$ & $52 \mathrm{~A}$ & 53 & $23 \mathrm{~A}$ & $38 \mathrm{~A}$ & $48 \mathrm{~A}$ & $50 \mathrm{~A}$ & $51 \mathrm{~A}$ & $52 \mathrm{C}$ \\
\hline $\mathrm{La}$ & 364 & 166 & 116 & 109 & 228 & 8.0 & 131 & 160 & 124 & 637 & 7.9 & 10.2 & 28.7 & 38.6 \\
\hline $\mathrm{Ce}$ & 750 & 288 & 226 & 157 & 362 & 14.8 & 199 & 205 & 873 & 1602 & 20.9 & 23.6 & 57.0 & 63.5 \\
\hline $\operatorname{Pr}$ & 72.2 & 26.3 & 22.1 & 14.3 & 31.9 & 1.6 & 19.8 & 19.7 & 101 & 156 & 2.1 & 2.5 & 6.0 & 7.0 \\
\hline $\mathrm{Nd}$ & 300 & 107 & 91.8 & 56.7 & 127 & 6.4 & 75.0 & 75.0 & 557 & 610 & 9.1 & 9.3 & 21.1 & 26.7 \\
\hline $\mathrm{Sm}$ & 54.1 & 18.8 & 17.2 & 9.4 & 21.8 & 1.2 & 13.5 & 13.1 & 198 & 108 & 2.7 & 1.8 & 3.9 & 4.7 \\
\hline $\mathrm{Eu}$ & 13.3 & 4.9 & 4.3 & 2.5 & 5.6 & 0.28 & 2.9 & 3.1 & 50.5 & 28.0 & 0.83 & 0.31 & 0.78 & 1.0 \\
\hline Gd & 69.4 & 26.4 & 22.7 & 14.8 & 31.5 & 1.2 & 15.3 & 17.9 & 205 & 155 & 3.3 & 1.5 & 3.1 & 5.2 \\
\hline $\mathrm{Tb}$ & 9.1 & 3.6 & 3.1 & 2.0 & 4.2 & 0.17 & 2.3 & 2.4 & 33.5 & 20.6 & 0.62 & 0.23 & 0.47 & 0.77 \\
\hline Dy & 52.3 & 21.3 & 18.6 & 12.8 & 25.6 & 0.94 & 13.9 & 14.4 & 179 & 115 & 4.4 & 1.4 & 2.8 & 4.8 \\
\hline Но & 10.8 & 4.7 & 4.0 & 2.9 & 5.6 & 0.19 & 2.9 & 3.1 & 31.8 & 22.2 & 0.91 & 0.27 & 0.54 & 0.95 \\
\hline Er & 28.6 & 13.0 & 10.9 & 8.4 & 15.9 & 0.55 & 7.9 & 8.3 & 77.0 & 53.6 & 2.8 & 0.81 & 1.5 & 2.7 \\
\hline $\mathrm{Tm}$ & 3.0 & 1.5 & 1.2 & 0.97 & 1.8 & 0.06 & 0.87 & 0.83 & 8.2 & 5.2 & 0.37 & 0.1 & 0.2 & 0.31 \\
\hline $\mathrm{Yb}$ & 18.3 & 9.4 & 7.7 & 6.5 & 11.7 & 0.49 & 5.2 & 4.8 & 49.6 & 27.6 & 2.7 & 0.82 & 1.7 & 2.0 \\
\hline $\mathrm{Lu}$ & 2.6 & 1.4 & 1.1 & 1.0 & 1.8 & 0.07 & 0.69 & 0.67 & 6.5 & 3.6 & 0.38 & 0.12 & 0.23 & 0.28 \\
\hline$\Sigma$ REE & 1747.87 & 692.25 & 546.57 & 398.89 & 874.16 & 35.98 & 490.12 & 528.84 & 2495.61 & 3544.5 & 59.00 & 52.87 & 128.94 & 158.62 \\
\hline Y & 475 & 233 & 183 & 152 & 293 & 7.1 & 113 & 144 & 864 & 871 & 20.8 & 7.7 & 13.2 & 34.2 \\
\hline U & 28.1 & 31.5 & 30.4 & 28.2 & 26.8 & 0.81 & 43.3 & 12.5 & 20.7 & 28.2 & 0.69 & 1.2 & 19.7 & 32.5 \\
\hline $\mathrm{P}_{2} \mathrm{O}_{5}(\%)$ & 22.8 & 22.9 & 23.4 & 28.4 & 26.3 & 0.38 & 28.5 & 24.9 & 7.0 & 27.2 & 0.06 & 0.07 & 0.09 & 16.9 \\
\hline$\Sigma \mathrm{REE} / \mathrm{P}_{2} \mathrm{O}_{5} \times 100$ & 0.77 & 0.3 & 0.23 & 0.14 & 0.33 & 0.94 & 0.17 & 0.21 & 3.57 & 1.3 & 9.22 & 7.34 & 14.33 & 0.09 \\
\hline$\Sigma R E E / Y$ & 3.67 & 2.97 & 2.99 & 2.63 & 2.98 & 5.1 & 4.36 & 3.67 & 2.89 & 4.07 & 2.84 & 6.88 & 9.74 & 4.64 \\
\hline$\Sigma \mathrm{REE} / \mathrm{U}$ & 62.29 & 21.95 & 17.96 & 14.16 & 32.64 & 44.42 & 11.32 & 42.17 & 120.62 & 125.65 & 85.51 & 43.69 & 6.53 & 4.88 \\
\hline $\mathrm{Ce} / \mathrm{La}$ & 2.06 & 1.74 & 1.94 & 1.44 & 1.58 & 1.84 & 1.51 & 1.28 & 7.02 & 2.51 & 2.67 & 2.32 & 1.98 & 1.65 \\
\hline $\mathrm{La}_{\mathrm{N}} / \mathrm{Yb}_{\mathrm{N}}$ & 1.72 & 1.52 & 1.3 & 1.46 & 1.68 & 1.43 & 2.16 & 2.85 & 0.22 & 1.99 & 0.25 & 1.09 & 1.46 & 1.59 \\
\hline Ce-anomaly & 0.02 & -0.02 & 0.004 & 0.08 & -0.04 & -0.02 & -0.07 & -0.12 & 0.18 & 0.09 & 0.08 & 0.06 & 0.02 & -0.05 \\
\hline
\end{tabular}

The frequency histogram of $\mathrm{Ce} / \mathrm{La}$ ratios is plotted in Fig. 7 and compared to seawater (Høgdahl et al. 1968), average phosphorites (Altschuler 1980) and average shale (Haskin \& Haskin 1966). The distribution of Ce/La ratios in the samples shows distinctive variability among sample groups. The $\mathrm{Ce} / \mathrm{La}$ ratios range from 2.15 to 3.92 in the Bílá Hora silty mudstones of unit BH 1 (mean 2.56), while they vary between 1.96 and 2.8 in the Pecínov mudstones (mean 2.28; Tabs 1-4). Both mean values are slightly higher than that of average world shale at $\sim 2$ (Haskin \& Haskin 1966). The tube-fill sample 23A at the base of Unit P3 (Pecínov Member) shows anomalous $\mathrm{Ce} / \mathrm{La}=7.02$. In the phosphate nodules of the Bílá Hora Formation (Unit BH 1), Ce/La is elevated and ranges from 3.88 to 5.78 (mean 4.85 ). The phosphate coprolites in basal part of the Teplice Formation show relatively low $\mathrm{Ce} / \mathrm{La}$ ratios ranging from 1.44 to 2.51 with mean $\mathrm{Ce} / \mathrm{La}=$ 1.88 , which is below that of average shale. Phosphatic sponges (samples 52A and 53) show lower Ce/La ratios (mean 1.40) than calcareous sponges (sample 42A) with
$\mathrm{Ce} / \mathrm{La}=1.84$. The glauconite bed of the Bílá Hora Formation at Plaňany quarry has $\mathrm{Ce} / \mathrm{La}=2.32$ compared to $\mathrm{Ce} / \mathrm{La}=1.98$ in the overlying claystone bed. All samples fall into the anoxic field of redox conditions of the environment and slow sedimentation rate estimated from the Ce-anomaly versus $\mathrm{Nd}$ abundance plot following Wright et al. (1987), with the exception of sponges (phosphatic and calcareous) which fall into the transitional zone (Fig. 8).

Unit P3 samples (Pecínov Member) show shalenormalized $(\mathrm{La} / \mathrm{Yb})_{\mathrm{N}}<1.0$ [except sample $24 \mathrm{~A}$ with $\left.(\mathrm{La} / \mathrm{Yb})_{\mathrm{N}}=1.34\right]$, whereas samples of unit P4 show $(\mathrm{La} / \mathrm{Yb})_{\mathrm{N}}>1.0$. The $(\mathrm{La} / \mathrm{Yb})_{\mathrm{N}}=0.22$ for tube-fill $23 \mathrm{~A}$ at the base of unit P3. The Bílá Hora Formation samples of unit 1 show variable $(\mathrm{La} / \mathrm{Yb})_{\mathrm{N}}$ ratios ranging from 0.46 to 1.43 with the mean $(\mathrm{La} / \mathrm{Yb})_{\mathrm{N}}=1.09$. At Plañany quarry the $(\mathrm{La} / \mathrm{Yb})_{\mathrm{N}}=1.47$ in the kaolinitic claystone bed and it is 1.06 in the glauconite sandstone bed. In the phosphate nodules LREE are significantly enriched relative to HREE with $(\mathrm{La} / \mathrm{Yb})_{\mathrm{N}}>1.7$ and mean $(\mathrm{La} / \mathrm{Yb})_{\mathrm{N}}=1.75$. Only sample 13A 
Table 5. Mean REE, $\mathrm{P}_{2} \mathrm{O}_{5}, \mathrm{Y}$ and $\mathrm{U}$ concentrations, Ce-anomaly and significant geochemical ratios of main sample groups.

\begin{tabular}{|c|c|c|c|c|c|c|c|c|c|c|}
\hline & $\begin{array}{l}\text { Pecínov } \\
\text { Member }\end{array}$ & $\begin{array}{l}\text { Bílá Hora } \\
\text { Formation }\end{array}$ & phosphate & phosphate & phosphatic & phosphatic & & & & \\
\hline & unit P3 & unit P4 & mean & $<1 \% \mathrm{P}_{2} \mathrm{O}_{5}$ & $>1 \% \mathrm{P}_{2} \mathrm{O}_{5}$ & mean & nodules & coprolites & sponges & tube-fills \\
\hline $\mathrm{La}$ & 27.8 & 25.6 & 26.7 & 25.6 & 28.2 & 26.6 & 88.2 & 197 & 146 & 381 \\
\hline $\mathrm{Ce}$ & 62.4 & 57.1 & 59.8 & 56.8 & 98.6 & 72.4 & 428 & 357 & 202 & 1237 \\
\hline $\operatorname{Pr}$ & 6.7 & 5.9 & 6.3 & 5.9 & 9.4 & 7.1 & 36.1 & 33.3 & 19.8 & 128 \\
\hline $\mathrm{Nd}$ & 25.1 & 21.5 & 23.3 & 21.6 & 40.0 & 28.5 & 165 & 137 & 75 & 584 \\
\hline $\mathrm{Sm}$ & 5.2 & 4.2 & 4.7 & 4.3 & 9.4 & 6.2 & 42.4 & 24.3 & 13.3 & 153 \\
\hline $\mathrm{Eu}$ & 1.1 & 0.90 & 0.97 & 0.93 & 2.2 & 1.4 & 10.5 & 6.1 & 3.0 & 39.2 \\
\hline Gd & 4.8 & 3.6 & 4.2 & 3.7 & 9.4 & 5.8 & 45.1 & 33.0 & 16.6 & 180 \\
\hline $\mathrm{Tb}$ & 0.75 & 0.58 & 0.67 & 0.55 & 1.4 & 0.87 & 6.8 & 4.4 & 2.4 & 27.0 \\
\hline Dy & 4.4 & 3.2 & 3.8 & 3.1 & 7.7 & 4.8 & 37.5 & 26.1 & 14.1 & 147 \\
\hline Ho & 0.87 & 0.64 & 0.76 & 0.60 & 1.4 & 0.92 & 6.9 & 5.6 & 3.0 & 27.0 \\
\hline $\mathrm{Er}$ & 2.5 & 1.8 & 2.1 & 1.7 & 3.7 & 2.5 & 16.7 & 15.3 & 8.1 & 65.3 \\
\hline $\mathrm{Tm}$ & 0.33 & 0.25 & 0.29 & 0.23 & 0.41 & 0.3 & 1.7 & 1.7 & 0.85 & 6.7 \\
\hline $\mathrm{Yb}$ & 2.4 & 1.8 & 2.1 & 1.7 & 2.7 & 2.1 & 9.8 & 10.7 & 5.0 & 38.6 \\
\hline $\mathrm{Lu}$ & 0.37 & 0.27 & 0.32 & 0.24 & 0.39 & 0.3 & 1.3 & 1.6 & 0.68 & 5.1 \\
\hline$\Sigma \mathrm{REE}$ & 144.52 & 127.41 & 136 & 126.95 & 214.85 & 159.91 & 896.89 & 851.96 & 509.83 & 3020.06 \\
\hline Y & 23.5 & 17.6 & 20.5 & 15.9 & 43.4 & 26.2 & 219 & 267 & 128 & 867 \\
\hline $\mathrm{U}$ & 5.0 & 2.7 & 3.8 & 2.6 & 19.2 & 8.8 & 28.6 & 29.0 & 27.9 & 24.5 \\
\hline $\mathrm{P}_{2} \mathrm{O}_{5}(\%)$ & 0.14 & 0.08 & 0.11 & 0.14 & 3.2 & 1.3 & 24.0 & 24.8 & 26.7 & 17.1 \\
\hline$\Sigma \mathrm{REE} / \mathrm{P}_{2} \mathrm{O}_{5} \times 100$ & 10.71 & 16.55 & 12.83 & 9.07 & 0.68 & 1.25 & 0.38 & 0.34 & 0.19 & 3.44 \\
\hline$\Sigma R E E / Y$ & 6.16 & 7.24 & 6.62 & 7.96 & 4.95 & 6.09 & 4.08 & 3.19 & 4.02 & 3.48 \\
\hline$\Sigma \mathrm{REE} / \mathrm{U}$ & 29.14 & 48.08 & 35.69 & 49.02 & 11.17 & 18.11 & 30.86 & 29.38 & 26.75 & 123.14 \\
\hline $\mathrm{Ce} / \mathrm{La}$ & 2.25 & 2.23 & 2.24 & 2.22 & 3.5 & 2.72 & 4.86 & 1.81 & 1.4 & 4.77 \\
\hline $\mathrm{La}_{\mathrm{N}} / \mathrm{Yb}_{\mathrm{N}}$ & 1 & 1.26 & 1.1 & 1.31 & 0.91 & 1.12 & 0.78 & 1.58 & 2.5 & 1.11 \\
\hline Ce-anomaly & 0.05 & 0.05 & 0.05 & 0.05 & 0.17 & 0.1 & 0.25 & 0.05 & -0.1 & 0.14 \\
\hline Mean $\Sigma$ LREE & 0.69 & 0.59 & 0.64 & 0.59 & 0.98 & 0.74 & 3.84 & 3.73 & 2.31 & 14.46 \\
\hline Mean $\Sigma$ MREE & 0.7 & 0.55 & 0.63 & 0.55 & 1.34 & 0.5 & 6.32 & 4.33 & 2.24 & 25.38 \\
\hline Mean $\boldsymbol{\Sigma}$ HREE & 0.62 & 0.46 & 0.54 & 0.43 & 0.82 & 0.58 & 3.34 & 3.32 & 1.92 & 13.48 \\
\hline
\end{tabular}

has $(\mathrm{La} / \mathrm{Yb})_{\mathrm{N}}=1.03$. Phosphate coprolites have $(\mathrm{La} / \mathrm{Yb})_{\mathrm{N}}$ of $1.30-1.99$ (mean 1.61) and the sponges have $(\mathrm{La} / \mathrm{Yb})_{\mathrm{N}}$ of 1.43 in the calcareous sponge (sample $42 \mathrm{~A}$ ) and $>2$ in the phosphatic sponges (Tabs 3,4). The shale-normalized $(\mathrm{La} / \mathrm{Sm})_{\mathrm{N}}$ ratio in the phosphate components is the lowest in the phosphate nodules (mean 0.38) and tube-fill deposits (mean 0.46) and the highest in the coprolites (mean 1.48) and the sponges (mean 2.01).

\section{Statistical processing}

Phosphorus, $\mathrm{Y}$ and $\mathrm{U}$ are positively correlated with the total REE content of the analyzed samples (Tab. 6). The correlation coefficients are $0.74,0.95$ and 0.80 , respectively. A trend in the correlation coefficients of $\mathrm{P}_{2} \mathrm{O}_{5}$ and $\mathrm{U} v s$. REE is apparent, slightly increasing from HREE to LREE, whereas the opposite trend is found in the case of $\mathrm{Y}$. Despite the fact that there are wide ranges in $\Sigma$ REE of the samples, the plot of $\Sigma$ REE vs. $\mathrm{P}_{2} \mathrm{O}_{5}$ (Fig. 2) shows a linear positive correlation between mean concentration values of main sample groups including non-phosphatic samples of Pecínov Member (units P3 and P4) and the Bílá Hora Formation (unit BH 1), slightly phosphatic samples of the Bílá Hora Formation (unit BH 1), phosphate nodules, mold, and coprolites. The phosphatic tube-fill samples, showing REE enrichment, and phosphatic sponges, showing REE depletion relative to $\mathrm{P}_{2} \mathrm{O}_{5}$, highlight deviations from the general correlation line. 
Factor analysis shows three statistically-deduced factors influencing the concentrations of the analyzed elements (Tab. 6). Factor 1 explains $\sim 75 \%$ of the variance and includes all REE with a mean correlation coefficient of $>0.8$, except La which shows a weaker correlation of 0.52 , increasing to 0.8 and 0.84 for $\mathrm{Ce}$ and $\mathrm{Pr}$ respectively, compared to $>0.9$ for all other REE. Factor 2 explains $\sim 12 \%$ of variance and positively influences the concentrations of $\mathrm{P}_{2} \mathrm{O}_{5}$ and $\mathrm{U}$. Factor 3 explains $\sim 6 \%$ of variance and mainly influences $\mathrm{La}$ and, to a lesser extent, $\mathrm{Ce}$ and $\mathrm{Pr}$.

\section{Discussion}

\section{Source of REE}

Several major sources of REE in the marine sedimentary environment are available: (i) deep ocean waters brought to shelf areas by upwelling currents together with $\mathrm{P}$ and $\mathrm{Si}$, (ii) marine pore fluids which may represent the major REE input into oceans (Sholkovitz et al. 1989,

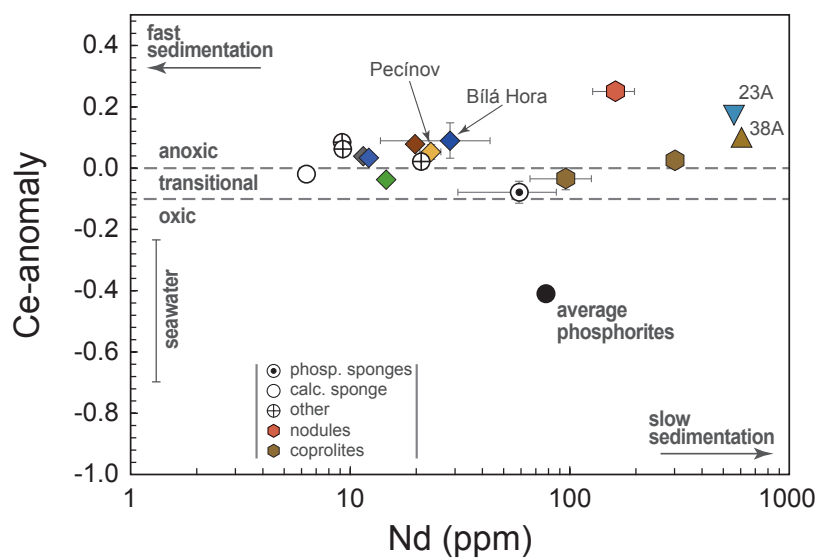

Figure 8. Ce-anomaly versus $\mathrm{Nd}$ contents in samples from this study. Mean values and one sigma uncertainties are plotted for mudstones (Pecínov, Bílá Hora), phosphate nodules, phosphate coprolites (save for Nd-rich sample 28A), and phosphate sponges. Nd-rich phosphate fill-tube samples 23A and 38 are plotted separately. See symbols in Fig. 3 for other samples. General sedimentation rates are depicted with arrows. Redox boundaries are after Wright et al. (1987). The range of Ce-anomaly in seawater is from Høgdahl et al. (1968); average $\mathrm{Nd}$ concentration and Ce-anomaly value of upwelling marine phosphorites is from Altschuler (1980). See main text for Ce-anomaly calculation.

Table 6. Statistical analysis.

\begin{tabular}{|c|c|c|c|c|c|c|c|c|}
\hline \multicolumn{5}{|c|}{ Correlation coefficients } & \multicolumn{4}{|c|}{ Factor analysis } \\
\hline & $\mathrm{Y}$ & $\mathrm{U}$ & $\mathrm{P}_{2} \mathrm{O}_{5}$ & $\mathrm{La}$ & & $\mathrm{F} 1(75 \%)$ & F2 $(12 \%)$ & $\mathrm{F} 3(6 \%)$ \\
\hline $\mathrm{La}$ & 0.87 & 0.76 & 0.76 & & $\mathrm{La}$ & 0.52 & 0.35 & 0.77 \\
\hline $\mathrm{Ce}$ & 0.94 & 0.78 & 0.73 & 0.92 & $\mathrm{Ce}$ & 0.8 & 0.36 & 0.42 \\
\hline $\operatorname{Pr}$ & 0.94 & 0.8 & 0.73 & 0.93 & $\operatorname{Pr}$ & 0.84 & 0.3 & 0.41 \\
\hline $\mathrm{Nd}$ & 0.94 & 0.81 & 0.74 & 0.92 & $\mathrm{Nd}$ & 0.91 & 0.29 & 0.27 \\
\hline $\mathrm{Sm}$ & 0.95 & 0.8 & 0.73 & 0.9 & $\mathrm{Sm}$ & 0.98 & 0.21 & -0.03 \\
\hline $\mathrm{Eu}$ & 0.94 & 0.77 & 0.72 & 0.9 & $\mathrm{Eu}$ & 0.98 & 0.2 & -0.02 \\
\hline Gd & 0.97 & 0.81 & 0.74 & 0.89 & $\mathrm{Gd}$ & 0.96 & 0.23 & 0.12 \\
\hline $\mathrm{Tb}$ & 0.98 & 0.78 & 0.72 & 0.86 & $\mathrm{~Tb}$ & 0.98 & 0.21 & 0.03 \\
\hline Dy & 0.98 & 0.76 & 0.72 & 0.86 & Dy & 0.97 & 0.22 & 0.05 \\
\hline Ho & 0.99 & 0.78 & 0.72 & 0.85 & Ho & 0.96 & 0.25 & 0.1 \\
\hline Er & 0.99 & 0.77 & 0.72 & 0.85 & $\mathrm{Er}$ & 0.96 & 0.26 & 0.12 \\
\hline $\mathrm{Tm}$ & 0.99 & 0.75 & 0.71 & 0.85 & $\mathrm{Tm}$ & 0.96 & 0.24 & 0.1 \\
\hline $\mathrm{Yb}$ & 0.99 & 0.76 & 0.71 & 0.85 & $\mathrm{Yb}$ & 0.95 & 0.24 & 0.07 \\
\hline $\mathrm{Lu}$ & 0.99 & 0.75 & 0.7 & 0.86 & $\mathrm{Lu}$ & 0.94 & 0.25 & 0.08 \\
\hline $\boldsymbol{\Sigma}$ REE & 0.95 & 0.8 & 0.74 & 0.94 & $\boldsymbol{\Sigma}$ REE & 0.85 & 0.33 & 0.39 \\
\hline $\mathrm{Y}$ & & 0.79 & 0.74 & 0.87 & $\mathrm{Y}$ & 0.89 & 0.32 & 0.31 \\
\hline $\mathrm{U}$ & & & 0.73 & 0.79 & $\mathrm{U}$ & 0.22 & 0.9 & 0.05 \\
\hline $\mathrm{P}_{2} \mathrm{O}_{5}$ & & & & 0.76 & $\mathrm{P}_{2} \mathrm{O}_{5}$ & 0.25 & 0.88 & 0.23 \\
\hline \multirow[t]{4}{*}{$\mathrm{Ce} / \mathrm{La}$} & 0.35 & 0.17 & 0.06 & 0 & $\mathrm{Ce} / \mathrm{La}$ & 0.64 & 0.27 & 0.58 \\
\hline & & & & & $\boldsymbol{\Sigma} \mathrm{REE} / \mathrm{P}_{2} \mathrm{O}_{5}$ & -0.15 & -0.78 & 0.01 \\
\hline & & & & & $\boldsymbol{\Sigma} \mathrm{REE} / \mathrm{Y}$ & -0.34 & -0.75 & -0.05 \\
\hline & & & & & $\boldsymbol{\Sigma} \mathrm{REE} / \mathrm{U}$ & 0.71 & -0.49 & 0.29 \\
\hline
\end{tabular}


Haley \& Klinkhammer 2003, Abbott et al. 2015), and (iii) continental detritus (Martin et al. 1976, Greaves et al. 1994) brought by rivers to the depositional marine environment sorbed on $\mathrm{Fe}-\mathrm{Mn}$ oxyhydroxides and/or organic matter, and desorbed back into ocean water under anoxic sedimentary conditions. Each of these alternatives holds its specific pattern of distribution.

The deep ocean water in shelf areas should mimic the REE pattern of seawater; having a distinctly negative Ce anomaly, paralleled by general enrichments in HREE. The continental source should reflect the REE distribution pattern of source rocks and their weathering derivatives, with or without a positive Ce-anomaly and/or enrichment in LREE. Rare earth elements derived from pore water sources usually show patterns influenced by diagenetic REE fractionation, controlled by local geochemical parameters such as redox potential. All trends are subject to alteration according to local sedimentary conditions and later diagenetic modifications (McArthur \& Walsh 1984, Ilyin 1998, Shields \& Stille 2001, Shields \& Webb 2004, Bright et al. 2009).

The shale-normalized patterns of almost all the samples do not resemble that of open seawater (except sample 48A). They do not have a negative Ce-anomaly typical of seawater and are enriched in the LREE, unlike seawater (Figs 3-6). The shale-normalized REE patterns of phosphate nodules show a positive Ce-anomaly and enrichment in the MREE producing a "bell-shaped" pattern. The mudstones of Pecínov Member (units P3 and P4) show generally flat patterns with slight LREE enrichments. Similar REE patterns are observed in the samples of the Bílá Hora Formation (unit BH 1), with the exception of those containing minor amounts of phosphate. In such a case they tend to show positive Ce-anomaly and the "bell-shaped" REE pattern. This is particularly apparent for the phosphatic tube-fill samples 23A and 38A (Figs 2, 5). The coprolites show identical patterns without Ce-anomaly and with less pronounced MREE enrichments (Fig. 4B).

The REE distribution observed in samples from this study suggests that the source of REE in the Cenomanian and Turonian sequences is not deep oceanic water and, by inference, deep oceanic upwelling currents. Perhaps the only exception to this is calcareous tube-fill sample 48A, showing enrichment in HREE, similar to open marine REE patterns, but without negative Ce-anomaly (Fig. 5). The source of REE in this sample could have been derived from open sea sources. Most REE in other samples are suggested to originate from terrigenous material derived from the extensively weathered rocks of the Bohemian Massif (dominated by felsic compositions) and transported by rivers to the sedimentary basin. All samples follow, to varying degrees, the pattern of granite and shale derived from felsic rocks, exhibiting Eu depletion and LREE enrichments (Fig. 6). The "bell-shaped" pattern, noted in the phosphate nodules and some phosphate-bearing tube-fills, could have been due to local variations in redox conditions, preferential substitutions in the apatite phase and/or later diagenetic processes, rather than by source rock composition.

\section{Depositional environment}

\section{Cerium anomaly}

Following the continental input to the marine environment, REE are further fractionated to varying degrees by local depositional environments. The diverse shapes of REE patterns have been interpreted as indicators of varying paleoenvironmental conditions (Lécuyer et al. 2004, Patrick et al. 2004, Fadel et al. 2015): the LREEenriched patterns are typical of coastal environments, the MREE-enriched patterns are indicative of estuarine or closed marine conditions, and the HREE-enriched patterns correspond to open marine conditions. This simple generalization is not fully acceptable in this study as the samples studied here come from various sequences deposited in different sedimentary environments ranging from shallow marine (Plaňany quarry) to deep marine (Pecínov and Úpohlavy quarries) environment, but only the phosphatic samples exhibit the MREE-enriched "bellshape" pattern. This suggests that MREE enrichment can be connected with phosphogenesis which took place in closed or semi-closed suboxic marine environments below sediment-water interface.

It was noted that the redox mobilization of $\mathrm{Ce}$ in pore waters is almost identical to its behavior in anoxic basins (De Baar 1983) and that the elevated $\mathrm{Ce}^{3+}$ concentrations expected in anoxic pore water environment can be removed by incorporation in authigenic minerals (such as apatite and glauconite) and/or by adsorptive scavenging. Trivalent $\mathrm{Ce}$ is rendered soluble in reducing environments. Most samples from this study show a variable extent of Ceanomaly in the anoxic field of Wright et al. (1987). The Ce-anomaly values of Pecínov Member mudstones (units P3 and P4 at Pecínov quarry; Tab. 1) vary within a range of $0.04-0.08$ which suggests poorly oxygenated conditions. The relatively poor oxygenation of the sedimentary environment indicated by the Ce-anomaly for units P3 and P4 is in agreement with the findings of Uličný et al. (1997) who suggested anaerobic conditions in the upper parts of the Pecínov Member (units P3 and P4). The mudstone samples from the overlying unit BH 1 of the Bílá Hora Formation show highly variable values of Ce-anomaly (Table 1) being higher in samples with $>1$ wt $\% \mathrm{P}_{2} \mathrm{O}_{5}$ than those with $<1 \mathrm{wt} \% \mathrm{P}_{2} \mathrm{O}_{5}$ suggesting greater oxygen deficiency associated with the presence of phosphates. 
The phosphate nodules, mechanically emplaced within unit BH 1 of the Bílá Hora Formation, have the largest and most uniform extent of Ce-anomaly among all samples, suggesting that they were originally formed in more pronounced conditions of anoxia compared to the samples of Pecínov and Bílá Hora siliciclasts, and even more than conditions of formation of the phosphate coprolites. These nodules appear to have witnessed the same depositional history, probably as wide spread phosphatic deposits formed in anoxic conditions below sediment-water interface, and were later reworked into younger and more oxygenated sediments.

The Ce-anomaly in the coprolites ranges from slightly positive to slightly negative values, but, as a bulk, they fall within the transitional field of Wright et al. (1987). The sponges show the most negative Ce-anomaly of the entire suite and fall in the transitional zone, approaching the boundary with the oxic field. The glauconite sandstone and kaolinitic claystone beds show positive Ce-anomaly and fall in the anoxic field.

In addition, $\mathrm{Ce} / \mathrm{La}$ ratio is considered as an indicator of redox conditions of the aqueous environment so that the higher the $\mathrm{Ce} / \mathrm{La}$ ratio the more oxygen-depleted the environment. This is well illustrated by the difference in $\mathrm{Ce} / \mathrm{La} \sim 0.35$ in open seawater (Høgdahl et al. 1968) versus $\mathrm{Ce} / \mathrm{La} \sim 2$ in average world shale (Haskin \& Haskin 1966). The histogram of $\mathrm{Ce} / \mathrm{La}$ ratios for samples from this study shows a distinctive variability among individual groups but $\mathrm{Ce} / \mathrm{La}$ ratios are $>1.3$ in the entire suite, well above seawater and phosphorites (Fig. 7). The results of this study collectively suggest that phosphogenesis during the latest Cenomanian/earliest Turonian took place under the most pronounced anoxic conditions recorded in the sequence. This is underscored by generally high mean $\mathrm{Ce} / \mathrm{La}$ values for all groups in this study, including the siliciclasts of the Bílá Hora Formation (unit BH 1; mean $\mathrm{Ce} / \mathrm{La}=2.65$ ), and the Pecínov member (units $\mathrm{P} 3$ and $\mathrm{P} 4$; mean $\mathrm{Ce} / \mathrm{La}=2.24$ ), averaging higher than that of average world shale of $\sim 2$ (Haskin \& Haskin 1966).

The $(\mathrm{La} / \mathrm{Sm})_{\mathrm{N}}$ ratio of $<0.35$ was used by Morad \& Felitsyn (2001) to characterize precipitation of apatite from suboxic to anoxic marine pore waters at shallow depth below sediment-water interface. The nearest to this value is found in the phosphate nodules and phosphatic tube fills with mean $(\mathrm{La} / \mathrm{Sm})_{\mathrm{N}}$ ratios of 0.38 and 0.46 , respectively, whereas the highest $(\mathrm{La} / \mathrm{Sm})_{\mathrm{N}}$ ratios are found in the phosphate sponges with a mean $(\mathrm{La} / \mathrm{Sm})_{\mathrm{N}}=2.01$, suggesting suboxic conditions for the former and more oxygenated environment for the latter. This indicates that the phosphate coprolites, with a mean $\mathrm{La} / \mathrm{Sm}_{\mathrm{N}}=1.48$, were phosphatized in a more oxic environment than the nodules.

Neodymium concentration was used as a gauge of sedimentation rate (Wright et al. 1987), given the relatively short residence time of $\mathrm{Nd}$ in marine environment, estimated at $3 \times 10^{2} \mathrm{yr}$, compared to $6.1 \times 10^{3} \mathrm{yr}$ for Ce and $1.1 \times 10^{4} \mathrm{yr}$ for La (Goldberg et al. 1963). The plot of Nd $v s$. Ce-anomaly (Fig. 8) shows that most samples from this study fall in the anoxic field of Wright et al. (1987), except the phosphatic sponges which fall in the transitional field suggesting mixed environments during phosphatisation. Sedimentation rate (based on $\mathrm{Nd}$ concentration) decreases progressively from the calcareous sponges, through the glauconitic sandstones of Pecínov Member and the Bílá Hora Formation in subsurface sections to their equivalent mudstones in the sampled exposures, phosphate nodules, coprolites and sponges. From $\mathrm{Nd}$ concentration data the tube-fill samples (samples 23A and 38) should have witnessed the lowest sedimentation rate. However, this trend may also be influenced by the variations in the proximity of REE source area to the depositional site and/ or input rate to the basin leading to variations in bulk REE concentrations (including $\mathrm{Nd}$ ) in these units and not merely the sedimentation rate as proposed by Wright et al. (1987).

\section{Trace element constraints}

Wright et al. (1987) have shown that biologic apatite debris exposed at or near the sediment-water interface for a long period of time in deep water sediments of the Atlantic and Pacific basins, where sedimentation rates are low, continue to accumulate REE to very high concentration levels. In contrast, lower concentrations of REE in apatite were observed in shallow water environments, where sedimentation rates are faster. Higher $\mathrm{REE} / \mathrm{P}_{2} \mathrm{O}_{5}$ ratios are thus suggested here to indicate lower sedimentation rates and, by inference, extended period of time for contact of the mineral phases with seawater. The uniform REE $/ \mathrm{P}_{2} \mathrm{O}_{5}, \mathrm{REE} / \mathrm{Y}, \mathrm{REE} / \mathrm{U}$ and $\mathrm{Ce} / \mathrm{La}$ ratios in the phosphate nodules support our suggestion that they were the result of breakdown of larger phosphate bodies that witnessed identical geochemical conditions during phosphate deposition and diagenesis. The REE/ $\mathrm{P}_{2} \mathrm{O}_{5}$ ratios are variable in the phosphate coprolites suggesting variable phosphatisation and diagenetic history. In the Pecínov Member at Pecínov quarry, higher ratios of $\mathrm{REE} / \mathrm{P}_{2} \mathrm{O}_{5}, \mathrm{REE} / \mathrm{U}$ and $\mathrm{REE} / \mathrm{Y}$ have been found in unit $\mathrm{P} 4$ relative to samples from unit $\mathrm{P} 3$, suggesting either higher mobilization rate of REE (relative to phosphorus) from their continental hosts (organic matter and $\mathrm{Fe}$ oxyhydroxides) or longer contact with seawater caused by lower sedimentation rate in unit $\mathrm{P} 4$.

This is underscored by the analyzed samples. Both depletion and enrichment in $\Sigma$ REE relative to $\mathrm{P}_{2} \mathrm{O}_{5}$ in the sponges and in the phosphatic tube-fill deposits, respectively, mark deviation from the uniform positive correlation between REE and $\mathrm{P}_{2} \mathrm{O}_{5}$ found in the other samples (Fig. 2). The phosphatic sponges were deposited 
in a shallow marine environment and experienced a limited contact with seawater prior to burial, which resulted in lower amounts of REE incorporated in the apatite phase. The phosphate nodules and coprolites were in contact with seawater for an extended period of time to accommodate more REE, suggesting slow deposition. The anomalous REE enrichment in samples of phosphate-bearing tubefill deposits, which are found at well-recognizable erosional and/or burrowed surfaces, may reflect, among other factors, higher terrigenous input of REE-bearing compounds to the depositional realm during extreme shallowing events induced by closer proximity to the continental source area during sea regression and seaward advance of the shoreline. Seawater consistently exhibits a positive $\mathrm{Gd}$ anomaly and negative $\mathrm{Tb}$ anomaly which were considered by De Baar et al. (1985a, b) compatible with the predicted speciation of $\mathrm{REE}^{3+}$ in seawater, in combination with scavenging as the dominant control on REE distribution in the oceans. It has been noted that the behavior of $\mathrm{Gd}$ appears always to be anomalous when compared to its neighbors $\mathrm{Eu}$ and $\mathrm{Tb}$ in the REE analysis of seawater of the Atlantic and Pacific oceans (Elderfield \& Greaves 1982; De Baar et al. 1983, 1985b). Also, source rocks may generally influence $\mathrm{Gd}$ abundance; $\mathrm{Gd}$ is usually enriched (relative to shale) in granites and in river waters (Piper 1974). The REE patterns of chondritenormalized felsic rocks (granites) show a distinctive trend of high LREE/HREE ratios with a pronounced Eunegative anomaly whereas those of mid-oceanic ridge basalts show depletion in LREE and almost flat, but elevated MREE and HREE values without Eu depletion (Piper 1974). Shale-normalized patterns of almost all samples show elevated $\mathrm{Gd}$ concentrations relative to $\mathrm{Tb}$. All samples and sample groups (normalized to chondrites) show a negative Eu-anomaly, similar in extent to that found in granites and shales derived from weathering of felsic rocks (Fig. 6). The negative Eu-anomaly, noticed in the phosphatic and non-phosphatic samples, can represent a signature inherited from source rocks of the Bohemian Massif. Hence, the REE transported in various forms to the sedimentary environment could have already been depleted in Eu leading to Eu-depleted bottom waters and the presence of $\mathrm{Eu}$ anomalies observed in the apatite and siliciclasts. It may also imply local reducing conditions, most likely caused by the microbial decomposition of organic matter as suggested by Trueman et al. (2003).

\section{Further geochemical corollaries}

Several hosts can accommodate REE in the non-phosphatic mudstones and sandstones, including glauconite, kaolinite, smectite and organic matter. The variation in $\mathrm{REE} / \mathrm{P}_{2} \mathrm{O}_{5}, \mathrm{REE} / \mathrm{Y}$ and $\mathrm{REE} / \mathrm{U}$ ratios in various strati- graphic units and phosphate components can be explained by their relative concentrations in the terrigenous input, sedimentation rate, duration of exchange with sea- or porewater, post depositional alteration and geochemical affinity towards various mineral hosts. Uranium and Y, like REE, are capable to replace $\mathrm{Ca}^{2+}$ in the apatite structure. The variation and occasional anomalous ratios of $\mathrm{REE} / \mathrm{Y}$ and $\mathrm{REE} / \mathrm{U}$ may indicate alternative sources or parent materials leading to different concentrations of these elements in the depositional and/or diagenetic environment. The non-phosphatic glauconitic siliciclasts of all the studied units are poor in REE; they contain 107-154 ppm $\Sigma$ REE and are slightly enriched in LREE, but without the "bell-shaped" pattern. Glauconites are usually enriched in LREE relative to HREE and most REE in glauconite are thought to come from terrigenous material rather than from deep oceanic sources (Fleet et al. 1980). The organic phases present in most samples may represent another host for REE in these rocks (Goldberg et al. 1963). The glauconitic mudstones of Pecínov Member and the Bílá Hora Formation encountered in subsurface sections have the lowest REE concentrations among all samples studied, due to their dominant quartz content and also due to higher sedimentation rate.

Rare earth elements are known to occur in trace to minor amounts in the structure of marine sedimentary carbonate-fluorapatite, which is the key mineral of phosphorites. The occurrence of REE in apatite is considered an example of coupled substitutions in which the replacement of divalent $\mathrm{Ca}$ by a trivalent rare earth is electrostatically balanced by the replacement of another $\mathrm{Ca}^{2+}$ ion by $\mathrm{Na}^{+}$ion or by substitution of $\mathrm{SiO}_{4}{ }^{4-}$ for $\mathrm{PO}_{4}{ }^{3-}$ (Altschuler et al. 1967, Fleet \& Pan 1995). Such a substitution is expected as a consequence of similar ionic radii of $\mathrm{Ca}$ and $\mathrm{REE}$, ranging from 0.86 to $1.04 \AA$ for $\mathrm{REE}^{3+}$ and $0.99 \AA$ for $\mathrm{Ca}^{2+}$ (Ilyin \& Ratnikova 1976, McLennan et al. 1979, Elderfield et al. 1981, Fleet \& Pan 1995). However, the amount of REE incorporated in the apatite structure can vary to a great extent depending on their ionic concentration in the depositional and/ or diagenetic environment and the contact time of the phosphate phase with sea- or pore water before burial.

In phosphate-bearing samples, carbonate-fluorapatite is the main host of REE. The new data from this study shows a positive covariation between REE and $\mathrm{P}_{2} \mathrm{O}_{5}$ contents (Fig. 2). The high correlation coefficient values between $\Sigma$ REE, $\mathrm{Y}$ and $\mathrm{U}$ with $\mathrm{P}_{2} \mathrm{O}_{5}(0.74,0.95$ and 0.80 , respectively) (Table 6), suggest apatite as the major host controlling the variations of these elements in the samples. However, the statistically-derived factors (Tab. 6) suggest that $\Sigma \mathrm{REE}$ and $\mathrm{Y}$ are controlled by a single factor which explains $75 \%$ of variance and demonstrates both a possible similar source material and strong geochemical affinity of $Y$ to the REE group in the sedimentary 
cycle. Factor 2 explains $12 \%$ of variance and controls the concentration variations of $\mathrm{P}_{2} \mathrm{O}_{5}$ and $\mathrm{U}$, which demonstrates strong geochemical affinity of $U$ to phosphate minerals in marine phosphorites, independent of that expressed by REE. It could also indicate redox control and source material variations. Within the REE group, La shows stronger correlation with a subordinate Factor 3, paralleled, to a lesser extent, by correlation with Ce and Pr. The assembly of these three REE in one factor may be explained in a way that La to Pr have the largest ionic radii in the group which may lead to some limitations in the structural substitutions for the smaller $\mathrm{Ca}^{2+}$ in apatite, the major REE host in these samples.

The relative MREE enrichment is linked with the highest abundance in the phosphate components, which are located in various stratigraphic horizons in the studied sequence and were deposited in various marine environments. This may suggest selective fractionation of MREE in the apatite due to crystal structural control. Such an elemental fractionation may be enhanced by anoxic to suboxic conditions of pore waters during precipitation of apatite and may have continued during the diagenesis. Preferential substitution may explain the enrichment of MREE in the studied phosphate nodules, coprolites, bivalve-mold and tube-fill samples and its absence in the non-phosphatic samples. The enrichment in MREE, or the so-called "bell-shaped" pattern may reflect equilibrium fractionation between the apatite phase and the slightly anoxic or suboxic seawater or pore water (Fadel et al. 2015). Middle REE are more suitable for such substitution, having more similar ionic radii to that of $\mathrm{Ca}^{2+}$.

However, preferential substitution of MREE in the apatite structure is not conclusively confirmed in the statistical analysis obtained in this study because correlation coefficients between $\mathrm{P}_{2} \mathrm{O}_{5}$ and MREE are not particularly significant. Several other factors may influence the concentration and pattern of REE distribution in marine sedimentary apatites. These include the original REE concentration and fractionation in the source rocks and their weathering products, geochemical processes during weathering and fluvial transport (such as sorption, co-precipitation and selective fractionation; Martin et al. 1976, Fleet 1984, Hoyle et al. 1984, Goldstein \& Jacobsen 1988), and mechanism and environment of phosphogenic processes. Other factors were suggested including the presence of biogenic mediation in the phosphogenic system, duration of contact with seawater, post depositional alteration, diagenetic modifications and texture of phosphate components (Wright et al. 1984, Ilyin 1998, Shields \& Stille 2001, Zanin \& Zamirailova 2009).

The "bell-shaped" REE patterns have also been explained as the effect of extensive late diagenetic recrystallization (Lécuyer et al. 2004), where REE uptake has been dominated by substitution in the apatite phase. The
REE patterns showing enrichments in MREE reported in fossil apatites by Reynard et al. (1999) were explained as due to the fractionation caused by substitution mechanisms in the apatite structure, which can take place during diagenesis. Therefore, it is not necessarily an environmental indicator of primary deposition. However, the REE pattern still has the potential to reflect the original early burial conditions and, by inference, the REE composition of the sediment surface or near-surface fluids, as suggested by many authors ( $c f$. Morad \& Felitsyn 2001, Fadel et al. 2015).

\section{REE and the anoxic peaks of the OAE2 at the Pecínov quarry section}

The large positive $\delta^{13} \mathrm{C}$ excursion spanning the Cenomanian-Turonian boundary is considered one of the largest and best documented carbon isotope excursion events in the geological record, called Ocean Anoxia Event 2 (OAE2) (e.g., Jenkyns et al. 1994, Hasegawa 1997, Jarvis et al. 2006, Gambacorta et al. 2015) and was conventionally interpreted as being related to accelerated burial of marine organic matter (Arthur et al. 1990). Among all analyzed samples the tube-fill sample 23A at the base of the unit $\mathrm{P} 3$ and all phosphate nodule samples collected from the unit BH 1 in the Pecínov quarry section exhibit the highest incompatible REE indices of anoxia, such as $\mathrm{Ce} / \mathrm{La}$ and the extent of Ce-anomaly. The $\mathrm{Ce} / \mathrm{La}$ is 7.02 in the former sample and ranges from 3.88 to 5.78 in the latter group of samples, whereas the Ce-anomaly is 0.18 and $0.22-0.28$, respectively (Tabs 3,4 ). The highest values of REE-based indices of anoxia found in sample $23 \mathrm{~A}$ conform to the maximum $\delta^{13} \mathrm{C}_{\text {org }}$ values recorded at the base of the unit $\mathrm{P} 3$, which was interpreted by Košt'ák et al. (2018) as the "b" peak of the carbon isotope excursion of the OAE2 (sensu Jarvis et al. 2006). The abrupt drop in $\delta^{13} \mathrm{C}_{\text {org }}$ values at the base of the unit BH 1 is thought to have been associated with the hiatus and reworking of the condensed "green sand" bed (Košt'ák et al. 2018). On the other hand, the elevated REE-based indicators of anoxia recorded in the phosphate nodules are interpreted here to be related to the "c" peak recorded by Jarvis et al. (2006) in the Culver Cliff (Isle of Wight) and Dover sections and reported missing at the Pecínov quarry section by Košték et al. (2018). The phosphate nodules found in the unit BH 1 (earliest Turonian) are reworked products of the underlying missing part of the sequence. Therefore, they should have originally formed within that part of the sequence carrying the peak $\delta^{13} \mathrm{C}$ excursion at the Cenomanian-Turonian boundary, identified by Jarvis et al. (2006) as the "c" peak of the OAE2, and these phosphate nodules carry the original REE signature of this anomalous anoxic event. 


\section{Conclusions}

The dominant proportion of REE load in the studied samples appears to come from terrigenous material of the highly weathered crystalline rocks of the Bohemian Massif and their derivatives (dominated by felsic composition), which were transported by rivers to the basin. The composition of source rocks has left their fingerprint in the relative enrichment of LREE over HREE, shown in shale- and chondrite-normalized patterns, paralleled by significant negative Eu-anomaly in the latter. The "bellshaped" pattern, noticed specifically in the phosphatebearing samples, is not entirely related to source rocks; it seems to have been produced mainly by local redox conditions (increased oxygen deficiency) promoting REE fractionation and REE composition of pore water. Preferential substitutions of MREE in the apatite phase and/or later diagenetic enrichment may have had some role in producing this pattern. The "bell-shaped" pattern is typical of phosphate-bearing units and components in the studied Cenomanian-Turonian sequence.

Based on the REE behavior shown in this study, all investigated units were deposited under various degrees of suboxic to anoxic conditions. The phosphate nodules show elevated levels of REE proxies for anoxia among the analyzed samples and can be related to the $\delta^{13} \mathrm{C}$ peak "c" of the OAE2. Unit P4 of Pecínov Member at Pecínov quarry was deposited under greater oxygen deficiency than the underlying unit P3. The tube-fill at the base of the unit P3 exhibits very high $\mathrm{Ce} / \mathrm{La}$ and pronounced Ce-anomaly, indicative of anoxia which conforms to the $\delta^{13} \mathrm{C}$ peak "b" of the OAE2. The phosphate-bearing silty mudstones at the base of unit BH 1 of the Bílá Hora Formation were deposited in less oxygenated environment than the nonphosphatic counterparts. The phosphatic coprolites of the Teplice Formation were deposited under moderately suboxic conditions.

Carbonate-fluorapatite is the major host of REE in the studied Cenomanian-Turonian sequence. Rare earth elements are most probably introduced via substitution for $\mathrm{Ca}$ in the apatite structure and are enriched over variable contact time with seawater and/or pore fluids before burial. Among the phosphate components, the phosphate nodules and coprolites appear to have spent longer time in contact with seawater, sufficient to accommodate higher levels of REE, suggesting slow deposition. Further REE enrichment in these phosphates could have taken place during later reworking. The phosphate sponges were phosphatized in shallow marine environment and had a more limited contact time with seawater prior to burial. Hence, lesser amounts of REE were incorporated in the apatite phase. The anomalously high concentrations of REE in the phosphatic tube-fill deposits cannot be fully attributed to extended time of contact with seawater. They may reflect higher terrigenous input of REE-rich materials during episodes of low sea levels and seaward advance of the shoreline where most REE could have been trapped in these tubes after mobilization. Local variations in redox conditions and later diagenetic processes could have also contributed to the REE enrichment in these tube sediments.

\section{Acknowledgments}

This work was supported by the internal research project No. 321620 of the Czech Geological Survey. Field sampling at Pecínov and Úpohlavy quarries was carried out with the help and guidance of Stanislav Čech. Radek Vodrážka provided valuable assistance in the field, furnished some of the samples and provided important geological information on the geology of Plaňany and Nová Ves quarries. Important help and remarkable assistance were provided by František Laufek during XRD analysis. We are grateful to Elena Antalová for chemical preparation of samples. We are grateful to two anonymous reviewers and editorial handling by Jiří Frýda.

\section{References}

Aba-Hussain, A.A., Al-Bassam, K. \& Al-Rawi, Y. 2010. Rare earth elements geochemistry of some Paleocene carbonate fluorapatites from Iraq. Iraqi Bulletin of Geology and Mining 6(1), 81-94.

Abed, A.M., Jaber, O., Alkuisi, M. \& SAdaqah, R. 2016. Rare earth elements and uranium geochemistry in the Al-Kora phosphorite province, Late Cretaceous, northwestern Jordan. Arab Journal of Geosciences 9(187), 1-19.

DOI 10.1007/s12517-015-2135-6

Abbott, A.N., Haley, B.A. \& McManus, J. 20115. Bottomsup: Sedimentary control of the deep North Pacific Ocean's $\varepsilon N d$ signature. Geology 43(11), 1035. DOI 10.1130/G37114.1

Ackerman, L., Magna, T., Rapprich, V., Upadhyay, D., Krátký, O., Čejková, B., Erban, V., Kochergina, Yu.V. \& HrstKA, T. 2017. Contrasting petrogenesis of spatially related carbonatites from Samalpatti and Sevattur, Tamil Nadu, India. Lithos 284-285, 257-275. DOI 10.1016/j.lithos.2017.03.029

Altschuler, Z.S. 1980. The geochemistry of trace elements in marine phosphorites. Society for Sedimentary Geology (SEPM) Special Publications 29, 19-30.

Altschuler, Z.S., Berman, S. \& Cuttitta, F. 1967. Rare earths in phosphorites - Geochemistry and potential recovery. USGS Professional Paper 375-B, B1-B9.

Anders, E. \& Grevesse, N. 1989. Abundances of the elements: Meteoritic and solar. Geochimica et Cosmochimica Acta 53, 197-214. DOI 10.1016/0016-7037(89)90286-X

Arthur, M.A., Jenkyns, H.C., Brumsack, H.J. \& Schlanger, S.O. 1990. Stratigraphy, geochemistry and paleoceanography of organic carbon-rich Cretaceous sequences, 75-119. In Ginsburg, R.N. \& Beaudoin, B. (eds) Cretaceous Resources 
Events and Rhythms: Background and Plans for Research. NATO Science Series C: Mathematical and Physical Sciences no. 304. Kluwer Academic Publications, Dordrecht.

BAAR, H.J.W. DE, 1983. The marine geochemistry of the rare earth elements. 278 pp. Ph.D. thesis, Massachusetts Institute of Technology \& Woods Hole Oceanographic Institution, USA.

BAAR, H.J.W. De, BACON, M.P. \& BREwer, P.G. 1983. Rare-earth distributions with a positive Ce anomaly in the western North Atlantic Ocean. Nature (London) 301, 324-327. DOI 10.1038/301324a0

BaAr, H.J.W. De, Brewer, P.G. \& Bacon, M.P. 1985 b. Anomalies in rare earth distributions in seawater: $\mathrm{Gd}$ and $\mathrm{Tb}$. Geochimica et Cosmochimica Acta 49, 1961-1969. DOI 10.1016/0016-7037(85)90090-0

BaAr, H.J.W. De, Bacon, M.P., Brewer, P.G. \& Bruland, K.W. 1985a. Rare earth elements in the Atlantic and Pacific Oceans. Geochimica et Cosmochimica Acta 49, 1943-1959. DOI 10.1016/0016-7037(85)90089-4

Bright, C.A., Cruse, A.M., Lyons, T.W., MacLeod, K.G. Glascock, M.D. \& Ethington, R.L. 2009. Seawater rareearth element patterns preserved in apatite of Pennsylvanian conodont. Geochimica et Cosmochimica Acta 73, 1609-1624. DOI 10.1016/j.gca.2008.12.014

British Geological Survey 2011. Rare Earth Elements Mineral Profile. Centre for Sustainable Mineral Development. http:// www.bgs.ac.uk/mineralsuk/home.html

ČECH, S. Klein, V., KŘiž, J. \& VAleČKA, J. 1980. Revision of the Upper Cretaceous stratigraphy of the Bohemian Cretaceous Basin. Věstník Ústředního ústavu geologického 55(5), 277-296.

Čech, S., Hradecká, L., Laurin, J., Štaffen, Z., Švábenická, I. \& UliČnÝ, D. 1996. Úpohlavy quarry: record of the late Turonian sea-level oscillations and synsedimentary tectonic activity. Stratigraphy and Facies of the Bohemian-Saxonian Cretaceous Basin, 32-42. In HornA, F., Tröger, K.A. \& VoIGt, S. (eds) Field Trip Guide, $5^{\text {th }}$ International Cretaceous Symposium, Freiberg.

Čech, S., Hradecká, L., Svobodová, M. \& Švábenická, L. 2005. Cenomanian and Cenomanian-Turonian boundary in the southern part of the Bohemian Cretaceous Basin, Czech Republic. Bulletin of Geosciences 80(4), 321-354.

Dobeš, P., Povondra, P. \& Kühn, P. 1987. Mineralogie a geochemie fosforitů české křídové pánve. Acta Universitatis Carolinae - Geologica 54, 145-170.

Elderfield, H. \& Greaves, M.J. 1982. The rare earth elements in sea water. Nature 296, 214-219. DOI $10.1038 / 296214 \mathrm{a} 0$

Elderfield, H. \& Pagett, R. 1986. REE in ichthyoliths: varIations with redox conditions and depositional environment. Science of Total Environment 49, 175-197. DOI 10.1016/0048-9697(86)90239-1

Elderfield, H., Hawkesworth, C.J., Greaves, M.J. \& Calvert, S.E. 1981. Rare earth elements geochemistry of oceanic ferromanganese nodules. Geochimica et Cosmochimica Acta 45, 513-528.DOI 10.1016/0016-7037(81)90184-8

Elderfield, H., Upstill-Goddard, R. \& Sholkovitz, E.R. 1990.
The rare earth elements in rivers, estuaries and coastal seas and their significance to the composition of ocean waters. Geochimica et Cosmochimica Acta 54, 971-991.

DOI 10.1016/0016-7037(90)90432-K

Emsbo, P., Mclaughlin, P.I., Breit, G.N., Du Bray, E.A. \& Koening, A.E. 2015. Rare earth elements in sedimentary phosphate deposits: Solution to the global REE crises? Gondwana Research 27, 776-785.

DOI 10.1016/j.gr.2014.10.008

Fadel, A., Žigaité, Ž., Blom, H. Pérez-Huerta, A., Jeffries, T., Märss, T. \& Ahlberg, E. 2015. Paleoenvironmental signatures revealed from rare earth element (REE) compositions of vertebrate microremains of the Vesika Bone Bed (Homerian, Wenlock) Saarema Island, Estonia. Estonian Journal of Earth Sciences 64(1), 36-41.

DOI 10.3176/earth.2015.07

FLEET, A.J. 1984. Aqueous and sedimentary geochemistry of the rare earth elements, 343-373. In Henderson, P. (ed.) Rare Earth Elements Geochemistry. Elsevier, Amsterdam.

FleEt, M.E. \& PAN, Y. 1995. Site preference of rare earth elements in fluorapatite. American Mineralogist 80, 329-335. DOI 10.2138/am-1995-3-414

Fleet, A.J., Buckley, H.A. \& Johanson, L.R. 1980. The rare earth element geochemistry of glauconites and celadonites. Journal of the Geological Society of London 137, 683-688. DOI 10.1144/gsigs.137.6.0683

FreY, F.A. \& Haskin, L.A. 1964. Rare earths in oceanic basalts. Journal of Geophysical Research 69, 775-785. DOI 10.1029/JZ069i004p00775

Gambacorta, G., Jenkyns, H.C., Russo, F., Tsikos, H., Wilson, P.A., Faucher, G. \& Erba, E. 2015. Carbon- and oxygenisotope records of mid-Cretaceous Tethyan pelagic sequences from the Umbria-Marche and Belluno Basins (Italy). Newsletters on Stratigraphy 48(3), 299-323. DOI $10.1127 / \operatorname{nos} / 2015 / 0066$

German, C.R. Holliday, B.P. \& Elderfield, H. 1991. Redox cycling of rare earth elements in the suboxic zone of the Black Sea. Geochimica et Cosmochimica Acta 55, 3553-3558. DOI 10.1016/0016-7037(91)90055-A

German, C.R., Masuzawa, T., Greaves, M.J., Elderfield, H. \& Edmond, J.M. 1995. Dissolved rare earth elements in the Southern Ocean: cerium oxidation and the influence of hydrography. Geochimica et Cosmochimica Acta 59(8), 1551-1558. DOI 10.1016/0016-7037(95)00061-4

Goldberg, E.D., Koide, M., Sсhmitt, R. \& Smith, R. 1963. Rare-earth distribution in the marine environment. Journal of Geophysical Rearch 68, 4209-4217. DOI 10.1029/JZ068i014p04209

Goldstein, S.J. \& JACOBSEN, S.B. 1988. Rare earth elements in river waters. Earth and Planetary Science Letters 89, 35-47. DOI 10.1016/0012-821X(88)90031-3

Greaves, M.J., Statham, P.J. \& Elderfield, H. 1994. Rare earth elements mobilization from marine atmospheric dust into seawater. Marine Chemistry 46, 255-260.

DOI 10.1016/0304-4203(94)90081-7

Hasegawa, T. 1997. Cenomanian-Turonian carbon isotope events recorded in terrestrial organic matter from northern 
Japan. Palaeogeography, Palaeoclimatology, Palaeoecology 130, 251-273.

Haley, B.A. \& Klinkhammer, G.P. 2003. Complete separation of rare earth elements from small volume seawater samples by automated ion chromatography: method development and application to benthic flux. Marine Chemistry 82, 197-200. DOI 10.1016/S0304-4203(03)00070-7

Haskin, M.A. \& Haskin, L.A. 1966. Rare earths in Europian shales: a redetermination. Science 154, 507-509.

DOI 10.1016/S0031-0182(96)00129-0

Høgdahl, O.T., Melsom, S. \& Bowen, V.T. 1968. Neutron activation analysis of lanthanide elements in sea water. American Chemical Society 73, 308-325.

Holserab, W.T. 1997. Evaluation of the implication of rareearth elements to paleoceanography. Palaeogeography, Palaeoclimatology, Palaeoecology 132(1-4), 309-323. DOI 10.1016/S0031-0182(97)00069-2

Hoyle, J., Elderfield, H. Gledhill, A. \& Greaves, M. 1984. The behavior of the rare earth elements during mixing of river and sea waters. Geochimica et Cosmochimica Acta 48, 143-150. DOI 10.1016/0016-7037(84)90356-9

ILYIN, A.V. 1998. Rare-earth geochemistry of "old" phosphorites and probability of syngenetic precipitation and accumulation of phosphate. Chemical Geology 144, 243-256. DOI 10.1016/S0009-2541(97)00134-4

Ilyin, A.V. \& Ratnikova, G.I. 1976. Rare earths distribution in the Hobso Gol phosphorites (Mongolia). Geochemistry International 13, 53-56.

Jarvis, I., Gale, A.S., Jenkyns, H.C. \& Pearce, M.A. 2006. Secular variation in Late Cretaceous carbon isotopes: a new $\delta^{13} \mathrm{C}$ carbonate reference curve for the CenomanianCampanian (99.6-70.6Ma). Geological Magazine 143, 561-608. DOI 10.1017/S0016756806002421

Jarvis, I., Burnett, W.C., Nathan, Y., Almbaydin, F.S.M., Atia, A.K.M., Castro, L.N. Flicoteaux, R., Hilmy, M.E., Hussain, V., Qutawnah, A.A., Serjani, A. \& Zanin, Y.N. 1994. Phosphorite geochemistry-state-of-the-art and environmental concerns. Ecologae Geologicae Helvetiae (Journal of the Swiss Geological Society) 87, 643-700.

Jenkyns, H.C., Gale, R.M. \& Corfield, R.M. 1994. Carbon- and oxygen isotope stratigraphy of the English Chalk and Italian Scoglia and its palaeoclimatic significance. Geological Magazine 131, 1-34. DOI 10.1017/S0016756800010451

Jochum, K.P., Nohl, U., Lammel, E., Stoll, B. \& Hofmann, A.W. 2005. GeoReM: a new geochemical database for reference materials and isotopic standards. Geostandards \& Geoanalytical Research 29, 333-338.

DOI 10.1111/j.1751-908X.2005.tb00904.X

Kemp, R.A. \& Trueman, C.N. 2003. Rare earth elements in Solnhofen biogenic apatite: geochemical clues to the palaeoenvironment. Sedimentary Geology 155, 109-127. DOI 10.1016/S0037-0738(02)00163-X

KidDER, D.L., Krishnaswamy, R. \& MAPES, R.H. 2003. Elemental mobility in phosphatic shales during concretion growth and implications for provenance analysis. Chemical Geology 198 (3-4), 335-353. DOI 10.1016/S0009-2541(03)00036-6

KošŤÁK, M., Čench, S., UličnÝ, D., SklenÁŘ, J., Ekrt, B.,
Mazuch, M. 2018. Ammonites, inoceramids, and stable carbon isotopes of the Cenomanian-Turonian OAE2 interval in Central Europe: Pecínov quarry, Bohemian Cretaceous Basin (Czech Republic). Cretaceous Research 87, 150-173. DOI 10.1016/j.cretres.2017.04.013

Lécuyer, C., Reynard, B. \& Granjean, P. 2004. Rare earth element evolution of Phanerozoic seawater recorded in biogenic apatites. Chemical Geology 204, 63-102.

DOI 10.1016/j.chemgeo.2003.11.003

Martin, E.E. \& Scher, H.D. 2004. Preservation of seawater Sr and $\mathrm{Nd}$ isotopes in fossil fish teeth: bad news and good news. Earth and Planetary Science Letters 220, 25-39.

DOI 10.1016/S0012-821X(04)00030-5

Martin, J.M., Högdahl, O.T. \& Рhilippot, J.C. 1976. Rare elements supply to the ocean. Journal of Geophysical Research 81, 3119-3124. DOI 10.1029/JC081i018p03119

McArthur, J.M. \& WALSh, J.N. 1984. Rare earth geochemistry of phosphorites. Chemical Geology 47, 191-220.

DOI 10.1016/0009-2541(84)90126-8

McLennan, S.M., Fryer, B.J. \& Yong, G.M. 1979. The geochemistry of the carbonate-rich Espanola Formation (Horonian) with emphasis on the rare earth elements. Canadian Journal of Earth Science 16, 230-239. DOI 10.1139/e79-022

Mitra, A., Elderfield, H. \& Greaves, M. 1994. Rare earth elements in submarine hydrothermal fluids and plumes from the Mid-Atlantic Ridge. Marine Chemistry 46, 217-235.

Morad, S. \& Felitsyn, S. 2001. Identification of primary Ceanomaly signatures in fossil biogenic apatite; implication for the Cambrian oceanic anoxia and phosphogenesis. Sedimentary Geology 143, 259-264.

DOI 10.1016/0304-4203(94)90079-5

Olivarez, A.M \& Owen, R.M. 1991. The europium anomaly of seawater: implication for fluvial versus hydrothermal REE inputs to the ocean. Chemical Geology 92, 317-328.

DOI 10.1016/0009-2541(91)90076-4

Ounis, A., Kocsis, L. ChaAbani, F. \& Pfeifer, H.R. 2008. Rare earth elements and stable isotope geochemistry $\left(\delta^{13} \mathrm{C}\right.$ and $\delta^{18} \mathrm{O}$ ) of phosphorite deposits in Gafsa Basin, Tunisia. Palaeogeography, Palaeoclimatology, Palaeoecology 268, 1-18. DOI 10.1016/j.palaeo.2008.07.005

Patrick, D., Martin, J.E., Parris, D.C. \& GrandstafF, D.E. 2004. Palaeoenvironmental interpretations of rare earth element signatures in mosasaurs (reptilian) from Upper Cretaceous Pierre Shale, central south Dakota, USA. Palaeogeography, Palaeoclimatology, Palaeoecology 212, 277-294. DOI 10.1016/S0031-0182(04)00315-3

Picard, S., Lécuyer, C., Barrat, J.-A., Garcia, J.-P. Dromart, G. \& Sheppard, S.M.F. 2002. Rare earth element contents of Jurassic fish and reptile teeth and their potential relation to seawater composition (Anglo-Paris Basin, France and England). Chemical Geology 186, 1-6. DOI 10.1016/S0009-2541(01)00424-7

PIPER, D.Z. 1974. Rare earth elements in the sedimentary cycle: A summary. Chemical Geology 14, 285-304. DOI 10.1016/0009-2541(74)90066-7

PIPER, D.Z. \& BAU, M. 2013. Normalized rare earth elements 
in water, sediments and wine: identifying sources and environmental redox conditions. American Journal of Analytical Chemistry 4, 69-83.

DOI 10.4236/ajac.2013.410A1009

Piper, D.Z., Baedecker, P.A., Crock, J.G., Burnett, W.C. \& Loebner, B.J. 1988. Rare earth elements in the phosphaticenriched sediment of the Peru shelf. Marine Geology 80, 269-285. DOI 10.1016/0025-3227(88)90093-X

Piper, D.Z., Veeh, H.H., Bertrand, W. \& Chase, R.L. 1975. An iron-rich deposit from the northeast Pacific. Earth and Planetary Science Letters 26(1), 114-120. DOI 10.1016/0012-821X(75)90183-1

Reynard, B., Lécuyer, C. \& Grandjean, P. 1999. Crystalchemical controls on rare-earth element concentrations in fossil biogenic apatites and implications for paleoenvironmental reconstructions. Chemical Geology 155(3-4), 233-241. DOI 10.1016/S0009-2541(98)00169-7

Ruhlin, D.E. \& Owen, R.M. 1986. The rare earth element geochemistry of hydrothermal sediments from the East Pacific Rise: Examination of a seawater scavenging mechanism. Geochimica et Cosmochimica Acta 50, 393-400. DOI 10.1016/0016-7037(86)90192-4

Sarkar, A., Sarangi, S., Ebihara, M., Bhattacharya, S.K. \& RAY, A.K. 2003. Carbonate geochemistry across the Eocene/ Oligocene boundary of Kutch, western India: implications to tectonic $\mathrm{O}_{2}$-poor conditions and foraminiferal extinction. Chemical Geology 201, 281-293.

DOI 10.1016/S0009-2541(03)00238-9

Shields, G.A. \& Stille, P. 1998. Stratigraphic trends in cerium anomaly in authigenic marine carbonates and phosphates: diagenetic alteration or sedimentary signals? 1387-1388. In V.M. Goldschmidt Conference, Toulouse 1998 (ed.) Extended abstracts. ULP-EOST-CNRS, Centre de Geochimie de la Surface, UMR 7517, Strasbourg, France.

Shields, G.A. \& Stille, P. 2001. Diagenetic constraints on the use of cerium anomalies as paleoseawater redox proxies: an isotopic and REE study of Cambrian phosphorites. Chemical Geology 175, 29-48. DOI 10.1016/S0009-2541(00)00362-4

Shields, G.A. \& Webb, G.E. 2004. Has the REE composition of seawater changed over geological time? Chemical Geology 204, 103-107. DOI 10.1016/j.chemgeo.2003.09.010

Sholkovitz, E.R. Landling, W.M. \& Lewis, B.L. 1994. Ocean particle chemistry: The fractionation of REE between suspended particles and seawater. Geochimica et Cosmochimica Acta 58, 1567-1579.

DOI 10.1016/0016-7037(94)90559-2

Sholkovitz, E., Piepgras, D.J. \& Jacobsen, S. 1989. The pore water chemistry of rare earth elements in Buzzards Bay sediments. Geochimica et Cosmochimica Acta, 2847-2856. DOI 10.1016/0016-7037(89)90162-2

TAYLOR, S.R. \& McLennan, S. 1985. The continental crust: Its composition and evolution. 312 pp. Blackwell, Oxford.

Trueman, C.N., Benton, J.M. \& Palmer, M.R. 2003. Geochemical taphonomy of shallow marine vertebrate assemblages. Palaeogeography, Palaeoclimatology, Palaeoecology 197, 151-169. DOI 10.1016/S0031-0182(03)00457-7

ULIČNÝ, D. 1997. Sedimentation in a reactivated intra-continental strike-slip fault zone: The Bohemian Cretaceous Basin, Central Europe. Gaea heidelbergensis 3(Abstracts $18^{\text {th }}$ IAS Regional Europian Meeting, Heidelberg), 347.

ULIČNÝ, D. 2001. Depositional systems and sequence stratigraphy of coarse-grained deltas in a shallow-marine, strike-slip setting: the Bohemian Basin, Czech Republic. Sedimentology 48, 599-628. DOI 10.1046/j.1365-3091.2001.00381.x

UličnÝ, D., Čech, S., Hradecká, L., HladíkovÁ, J. \& Laurin, J. 1996. Pecínov quarry: the record of mid-Cenomanian through early Turonian sea-level changes and related events, Part 2: Sea-level changes and geochemical anomalies across

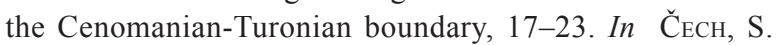
et al. (eds) Stratigraphy and facies of the BohemianSaxonian Cretaceous Basin. Guide to field trip B1. Fifth International Cretaceous Symposium and Second Workshop on Inoceramids, Freiberg, Germany, September 1996.

Uličný, D., Hladíková, J., Attrep Jr., M.J., Č́ech, S., HraDECKÁ, L. \& Svobodová, M. 1997. Sea-level changes and geochemical anomalies across the Cenomanian-Turonian boundary: Pecínov quarry, Bohemia. Palaeogeography, Palaeoclimatology, Palaeoecology 132, 265-285. DOI 10.1016/S0031-0182(97)00055-2

VALEČKA, J. \& SKoČEK, V. 1991. Late Cretaceous lithoevents in the Bohemian Cretaceous Basin, Czechoslovakia. Cretaceous Research 12, 561-577. DOI 10.1016/0195-6671(91)90031-7

VodrážKa, R., Sklenár̆, J., Čech, S., Laurin, J. \& HradeckÁ, L. 2009. Phosphatic intraclasts in shallow-water hemipelagic strata: a source of palaeoecological, taphonomic and biostatigraphic data (Upper Turonian, Bohemian Cretaceous Basin). Cretaceous Research 30(1), 204-222.

DOI 10.1016/j.cretres.2008.07.007

Wiese, F., Čech, S., Ekrt, B., KošŤÁk, M., Mazuch, M. \& Voigt, S. 2004. The Upper Turonian of the Bohemian Cretaceous Basin (Czech Republic) exemplified by the Úpohlavy working quarry: integrated stratigraphy and paleoceanography of a gateway to the Tethys. Cretaceous Research 25, 329-352. DOI 10.1016/j.cretres.2004.01.003

Wilde, P., Quinbyhunt, M.S. \& Erdtmann, B.D. 1996. The whole-rock cerium anomaly: a potential indicator of eustatic sea-level changes in shales of the anoxic facies. Sedimentary Geology 101(1-2), 43-53. DOI 10.1016/0037-0738(95)00020-8

Windom, H.L. 1969. Atmospheric dust records in permanent snowfields: implication to marine sedimentation. Geological Society of America Bulletin 80, 761-782.

DOI 10.1130/0016-7606(1969)80[761:ADRIPS]2.0.CO;2

Wright, J. Schrader, H. \& Holserab, W.T. 1987. Paleoredox variations in ancient oceans recorded by rare earth elements in fossil apatite. Geochimica et Cosmochimica Acta 51, 631-644. DOI 10.1016/0016-7037(87)90075-5

Wright, J., Seymour, R.S. \& Shaw, H.F. 1984. REE and Nd isotopes in conodont apatite: variations with geological age and depositional environment, 325-340. In Clark, D.L. (ed.) Conodont Biofacies and Provincialism. Geological Society of America Special Paper 196. DOI 10.1130/SPE196-p325

Zanin, Y. \& Zamirailova, A. 2009. Rare earth elements in supergene phosphorites. Geochemistry International 47, 282-296. DOI 10.1134/S0016702909030069 
Žítt, J., Nekvasilová, O., Hradecká, L., Svobodová, M. \& ZÁruba, B. 1998. Rocky coast facies of the Unhošt'Tursko high (Late Cenomanian-Early Turonian, Bohemian Cretaceous Basin). Acta Musei Nationalis Pragae, Series B, Historia Naturalis 54(3-4), 79-116.
Žítt, J., Vodráž́ka, R., Hradecká, L. \& Svobodová, M. 2010. Palaeoenvironments and facies on a progressively flooded rocky island (Upper Cenomanian-Lower Turonian, Bohemian Cretaceous Basin). Journal of the National Museum (Prague), Natural History Series 179(22), 223-234. 